\title{
The essentiality of sulfur is closely related to nitrogen metabolism: a clue to hyperhomocysteinaemia
}

\author{
Yves Ingenbleek ${ }^{1 *}$ and Vernon R. Young ${ }^{2}$ \\ ${ }^{1}$ Laboratory of Nutrition, Faculty of Pharmacy, University Louis Pasteur, 74 Route du Rhin, 67401 Illkirch, France \\ ${ }^{2}$ Laboratory of Human Nutrition, Massachusetts Institute of Technology, 77 Massachusetts Avenue, \\ Cambridge, MA O2139-4307, USA
}

\begin{abstract}
$\mathrm{N}$ and $\mathrm{S}$ metabolisms are closely interwoven throughout both the plant and animal kingdoms. The essentiality of $\mathrm{S}$ relates to its participation in the structure of S-containing amino acids (SAA), to its inclusion in many sulfonated molecules, and to a myriad of metabolic and catalytic reactions of vital importance. Methionine (Met) is the indispensable SAA supplied by food proteins and its plasma homeostasis is achieved via a number of highly efficient regulatory mechanisms. In all conditions characterised by a negative body protein balance such as in dietary restriction or cytokine-induced hypercatabolic losses, $\mathrm{N}$ and $\mathrm{S}$ endogenous pools manifest parallel tissue depletion rates. Adaptive conservation of $\mathrm{N}$ and $\mathrm{S}$ body stores is reached by a functional restraint of the trans-sulfuration cascade, through the depression of cystathionine $\beta$-synthase activity. As a result, upstream accumulation of homocysteine favours its re-methylation conversion to Met which helps maintain metabolic pathways of survival value. In addition to the measurement of vitamin indices, that of plasma transthyretin, a sensitive marker of protein nutritional status, is proposed to identify the fluctuations of the total body $\mathrm{N}$ component accountable for the alterations of homocysteine concentrations in body fluids.
\end{abstract}

Sulfur biology: Methionine: Homocyst(e)ine: Protein metabolism: Inflammatory disorders

\section{Introduction}

Homocysteine (Hcy) is a metabolically important amino acid (AA) generated by the enzymic de-methylation of methionine (Met) and is situated at a crucial crossroad regulating the fate of S-containing compounds. Hcy may be either re-methylated through the activity of Met synthase (EC 2.1.1.13) or irreversibly lost as a catabolite of S-containing AA (SAA) metabolism through the action of cystathionine (Cysta) $\beta$-synthase (CßS; $E C$ 4.2.1.22).

Hyperhomocysteinaemia is an acquired metabolic disorder found in apparently healthy individuals and recognised of increasing importance for health in the general population (Finkelstein, 2000; Refsum et al. 2004). The condition has been determined to be an independent and graded risk factor for thrombovascular lesions unrelated to hypercholesterolaemia, arterial hypertension, diabetes and smoking (McCully, 1996; Hankey \& Eikelboom, 1999). Considerable efforts have been undertaken in recent years to identify the causal factors responsible for its occurrence and to clarify the aetiopathogenic mechanisms implicated in tissue damage. To date, it has been established that dietary folate (Kang et al. 1987) and cobalamin (Stabler et al. 1990) shortage are both capable of depressing the activity of Met synthase, favouring the downstream accumulation of Hcy in extracellular fluids. Moreover, dietary pyridoxine deprivation may contribute to impair $C \beta S$ activity, the rate-limiting step initiating the trans-sulfuration cascade (Ubbink et al. 1996), thereby promoting the upstream sequestration of Hcy.

Preventive and/or therapeutic supplementation trials have highlighted that the three water-soluble vitamins do not operate with the same degree of potency on the enzymic machinery regulating Met homeostasis (Ubbink, 1997; Weir \& Scott, 1998). Dietary folate is regarded as a most important factor whereas pyridoxine appears to be less critical. Cobalamin deficiency occupies an intermediary position particularly affecting vegans. Recent studies using stepwise multiple regression analysis have concluded that folate and cobalamin deprivation, working together,

\footnotetext{
Abbreviations: AA, amino acid; C $\beta S$, cystathionine $\beta$-synthase; Cys, cysteine; Cysta, cystathionine; Hcy, homocysteine; IAA, indispensable amino acid; Met, methionine; MM, molecular mass; PEM, protein-energy malnutrition; SAA, S-containing amino acid; SAH, S-adenosylhomocysteine; SAM, S-adenosylmethionine; Tau, taurine; TBN, total body N; TTR, transthyretin.

*Corresponding author: Dr Yves Ingenbleek, fax +33 3902443 17, email ingen@ pharma.u-strasbg.fr
} 
account for $28 \%$ of the variance in total Hcy concentrations (Pancharuniti et al. 1994), whereas the contribution played by folate, cobalamin and pyridoxine taken as a whole ranges from about 35 to $40 \%$ of Hcy variance (Lussier-Cacan et al. 1996). In an attempt to explain much of the remaining variation, we postulate that the gap might be identified by largely considering the integrative aspects of total body $\mathrm{N}(\mathrm{TBN})$ as a major determinant of Met and Hcy homeostasis (Ingenbleek et al. 2002; Ingenbleek \& Young, 2002).

Our approach is grounded on the hypothesis that in any morbid condition resulting from either reduced $\mathrm{N}$ intake or excessive $\mathrm{N}$ losses, causing the downsizing of TBN, leads to depression in the trans-sulfuration pathway, with stimulation of the re-methylation of Hcy to Met. The concept implies that a functional C $\beta S$ blockade is an N-status-sensitive step, allowing the conservation of Met to maintain adaptive mechanisms of survival importance under nutritional and/or stressful disorders (Ingenbleek et al. 2002). Furthermore, the N-dependent component of acquired hyperhomocysteinaemia is best appraised by the serial measurement of plasma transthyretin (TTR; previously named pre-albumin) whose fluctuations are correlated with a shrinking or expanding of TBN (Ingenbleek \& Young, 2002). The present review is designed to assemble and evaluate all available information linking $\mathrm{S}$ essentiality to $\mathrm{N}$ metabolism and to provide substantial support for our hypothesis.

\section{The natural cycle of sulfur-containing compounds}

Astrophysical data and the chemical analysis of meteorites point to the participation of $\mathrm{S}$ in stellar evolution. There is geological evidence that $\mathrm{S}$ was present early amongst primordial compounds, either in free form, combined with other elements $(\mathrm{N}, \mathrm{O}, \mathrm{Si}, \mathrm{Fe})$ or in the reduced form of hydrogen sulfide $\left(\mathrm{H}_{2} \mathrm{~S}\right.$; Holland, 1974; Winnewisser \& Herbst, 1987; Wächtershäuser, 2000). For example, the theory of a pressurised Fe-S world suggests an autotrophic metabolism of low-molecular-mass (MM) constituents in an environment of iron sulfide and hot magmatic exhalations (Wächtershäuser, 2000). In the earth's crust, S naturally occurs as a mixture of four isotopes, the most abundant being ${ }^{32} \mathrm{~S}(95 \cdot 1 \%)$. The availability of $d$-orbitals for bonding allows $\mathrm{S}$ to assume eight different valencies ranging from -2 to +6 (Huxtable, 1986). The most oxidised and most stable state is represented by the physiologically inert $\mathrm{SO}_{4}{ }^{2-}$ oxyanion, whereas sulfide $\left(\mathrm{S}^{2-}\right)$ constitutes the most reduced and reactive state. From the former to the latter, all intermediate species exhibit increasing instability and reacting capacity (Huxtable, 1986).

In the anaerobic atmosphere of early geological times, the biological cycle of $\mathrm{S}$ is thought to have been initiated by micro-organisms transforming $\mathrm{SO}_{4}^{2-}$ to inorganic $\mathrm{H}_{2} \mathrm{~S}$. This reducing process is a form of primitive respiration requiring considerable energy from bacteria and fungi. The production and accumulation of $\mathrm{H}_{2} \mathrm{~S}$ has resulted in profound geochemical consequences favouring the emergence of anaerobic life on earth (Sult \& Kulp, 1959). The growth of both oxidising and reducing micro-organisms and the later occurrence of photosynthesis in microscopic plants has created reciprocal exchanges between anaerobic and aerobic ecosystems (Kelly, 1980). It may be worth recalling that $\mathrm{S}$ is located directly below $\mathrm{O}$ in the periodic table of elements. The progressive enrichment in $\mathrm{O}_{2}$ of the atmosphere has favoured the evolution of higher plants and aerobic animals. Remnants of primitive ecosystems still remain, largely confined to inhospitable places such as swamps, volcanoes and ocean beds (Mitchell, 1996).

\section{Regulation of sulfur metabolism in the vegetable kingdom}

A large number of micro-organisms and plants utilise reduced or oxidised $\mathrm{S}$ compounds as donors or acceptors of electrons with the capacity to reduce precursor molecules to the lowest oxidation states. These assimilatory reducing processes are highly regulated and share a close relationship with $\mathrm{N}$ metabolism. Their precursor anions found in the environment are usually available to the plant as $\mathrm{SO}_{4}{ }^{2-}$ and $\mathrm{NO}_{3}{ }^{-}$, their maximum oxidised forms (Mohr \& Schopfer, 1994). The cellular uptake of these oxyanions displays multiphasic characteristics along which $\mathrm{K}_{\mathrm{m}}$ and $\mathrm{V}_{\max }$ values are modified following plant requirements. The permeation systems involve both active accumulation using saturable (carrier-mediated) components and non-saturable passive diffusion (Mohr \& Schopfer, 1994). $\mathrm{SO}_{4}{ }^{2-}$ and $\mathrm{NO}_{3}{ }^{-}$must undergo reductions to the lowest oxidation states through the stimulation of sulfate and nitrate reductase enzymes to yield $\mathrm{SH}$ and $\mathrm{NH}_{4}$, respectively. $\mathrm{SH}$ is then transferred to the O-acetylserine molecule whose decay allows the formation of cysteine (Cys) whereas $\mathrm{NH}_{4}$ is converted to glutamine through the ATP-dependent activation of glutamine synthetase (Mohr \& Schopfer, 1994). These metabolic pathways mainly occur in the leaves during photosynthesis, releasing Cys and glutamate as precursor substrates for the production of most other S- and N-containing organic molecules. Tightly regulated mechanisms operate to prevent the excessive accumulation or shortage of $\mathrm{S}$ and $\mathrm{N}$ components. The rate of $\mathrm{SO}_{4}{ }^{2-}$ uptake and transport by the plant is rapidly depressed as a result of an expanded intracellular sulfate pool (Smith, 1975) but is also subject to the negative feedback control of Cys and Met concentrations (Hart \& Filner, 1969). Overfeeding the plant with Cys involves its breakdown to $\mathrm{SO}_{4}^{2-}$ by degradative enzymes. In contrast, sulfate deficiency in the medium stimulates the ATP-sulfurylase activity of cultured tobacco cells, driving a greater proportion of the available $\mathrm{SO}_{4}{ }^{2-}$ into reducing processes (Reuveny \& Filner, 1977) while inhibiting the activity of nitrate reductase, the rate-limiting enzyme governing $\mathrm{NO}_{3}^{-}$assimilation (Friedrich \& Schrader, 1978). The data indicate that $\mathrm{S}$ bioavailability works as a limiting factor for protein synthesis and plant growth. Deprivation of $\mathrm{S}$ resources causes failure to thrive and complete exhaustion leads to cessation of growth (Huxtable, 1986). The accumulation of $\mathrm{NO}_{3}^{-}$and of dispensable $\mathrm{AA}$ in free form (Bergmann, 1981) reflects either the inability of the plant to achieve an adequate rate of protein synthesis and deposition, or the catabolic breakdown of fully mature endproducts. Under normal circumstances, the cellular uptake of S and $\mathrm{N}$ in most higher plants and their incorporation into protein molecules operates along narrowly fluctuating $\mathrm{S}: \mathrm{N}$ 
molar ratios ranging from 1:31 to 1:40 (Dijkshoorn \& van Wijk, 1967). Likewise, and despite an almost 3000-fold variation in the medium sulfate, there exists a striking constancy in the rate of production of reduced $\mathrm{SH}$ and $\mathrm{NH}_{4}$ groups and in the synthesis of Cys and Met anabolites (Datko et al. 1978). These two S-containing AA represent 80 to $90 \%$ of all vegetable protein-bound S molecules (Huxtable, 1986). The concentrations of free Cys and free Met in higher plants is normally low and relatively constant even when the external S supply varies over a wide range of levels (Datko et al. 1978).

\section{Regulation of sulfur metabolism in the animal kingdom}

The animal kingdom is unable to reduce $\mathrm{SO}_{4}{ }^{2-}$ to sulfide or to produce SAA and must rely on the plant kingdom, bacteria and fungi for these converting processes. Met is one of the eight nutritionally indispensable AA (IAA) whose dietary intake in man is, therefore, obligatory for the synthesis of body proteins, maintenance of normal growth and vital activities. The molecule was discovered by Mueller (1923) and its essentiality was demonstrated by the growth retardation observed in rats given Met-free diets (Womack et al. 1937). S is the seventh most abundant element after $\mathrm{H}, \mathrm{C}, \mathrm{O}, \mathrm{N}, \mathrm{Ca}$ and $\mathrm{P}$ in the tissues of higher vertebrates. Thus, the body of a healthy adult man, weighing $70 \mathrm{~kg}$, contains about $140 \mathrm{~g} \mathrm{~S}$ (4400 mmol) or about the same as that of total K (140 g; $3600 \mathrm{mmol})$ (Forbes, 1996); each element thus represents $0.2 \%$ of body weight. The $\mathrm{S}: \mathrm{N}$ molar ratio $(4400 \mathrm{mmol}: 64 \mathrm{~mol}$ or $1: 14 \cdot 5)$ is higher than that recorded for plant tissue but is similar to the $1: 14.5$ ratio characteristic of animal proteins (Peters \& Van Slijke, 1931; Kennedy, 1974). Although the tissue distributions of $\mathrm{S}$ and $\mathrm{N}$ are not strictly aligned and that part of the total $\mathrm{S}$ pool is involved in the structure of lipid and carbohydrate components, the higher overall abundance of $\mathrm{S}$ leads to the view that it has a relatively greater degree of involvement in the animal economy. As a corollary, most plants used for human consumption reveal a limiting Met content in relation to human requirements. Indeed, Met may become a limiting nutritional factor in some vegetable products, notably in legumes (Young \& Pellet, 1994), particularly for the young growing infant and child (Beach et al. 1942).

An important biological function of Met is in the initiation of protein synthesis which starts with the attachment of a free Met molecule to initiator transfer RNA to yield formyl-methionyl-tRNA, launching the process of mRNA translation (Rudland \& Clark, 1972; Flaim et al. 1982). Met is also the major donor of methyl $\left(\mathrm{CH}_{3}\right)$ groups (Cantoni, 1951). Through the catalytic activation of Met adenosyltransferase (EC 2.5.1.6) Met condenses with ATP, yielding the dephosphorylated S-adenosylmethionine (SAM) molecule whose de-methylation releases, in turn, S-adenosylhomocysteine (SAH; Finkelstein, 1990). SAM serves as a proximal $\mathrm{CH}_{3}$ donor for more than 100 acceptor substrates, including nucleic acids, myelin, creatine, phospholipids, neurotransmitters, hormones, polyamines and AA (Giulidori et al. 1984; Fig. 1). The liver is the main site where most transmethylation reactions take place with the methyl groups supplied from dietary sources or resulting from the de novo synthesis of endogenous molecules (Mudd \& Poole, 1975). The enzymic hydrolysis of SAH allows the recycling of the adenosyl moiety and the production of Hcy (Finkelstein, 1990). The SAM:SAH ratio is frequently proposed as an indicator of cellular transmethylation potential (Cantoni, 1985). However, and because SAH is a potent inhibitor of SAM-dependent methylation reactions, more recent studies have advocated that an increased SAH intracellular concentration might be more consistently associated with hypomethylating capacities (Caudill et al. 2001).

Hcy is not incorporated into proteins via peptide-bond synthesis but rather constitutes a transitory branch-point regulating Met metabolism. On the one hand, Hcy may be re-methylated mainly through the stimulation of Met synthase. This is a rate-limiting enzyme requiring $\mathrm{CH}_{3}$ from $\left[\mathrm{N}^{5}\right] \mathrm{CH}_{3}$-tetrahydrofolate, the reduced product of $\left[\mathrm{N}^{5-10}\right]$ methylenetetrahydrofolate released by the activation of a specific reductase (methylenetetrahydrofolate reductase; Finkelstein, 1990). Several point mutations have been found on the methylenetetrahydrofolate reductase gene, including a thermolabile 677 cytosine-to-thymine mutation causing an alanine-to-valine substitution in the enzyme protein whose activity is normally dependent upon riboflavin (vitamin $\mathrm{B}_{2}$ ) coenzyme bioavailability (Hustad et al. 2000);

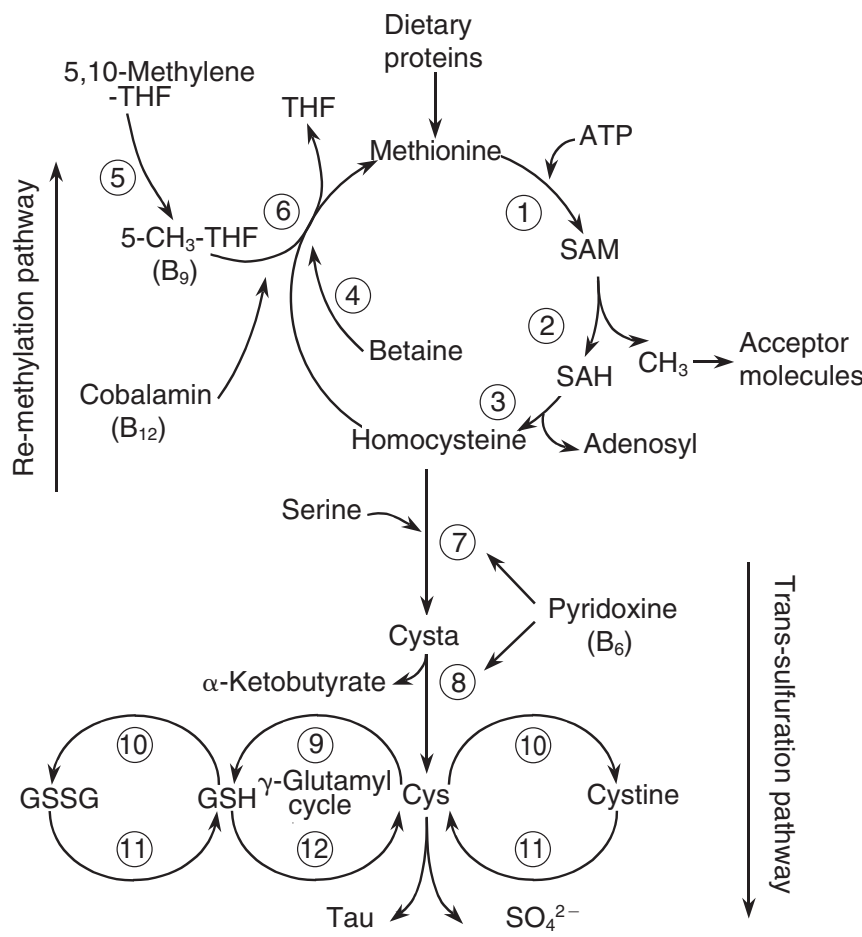

Fig. 1. Schematic outline of methionine (Met) and homocysteine pathways. THF, tetrahydrofolate; SAM, adenosylmethionine; $\mathrm{SAH}$, adenosylhomocysteine; Cysta, cystathionine; Cys, cysteine; Tau, taurine; (1), Met adenosyltransferase; (2), SAM methyltransferases; (3), adenosylhomocysteinase; (4), betainehomocysteine methyltransferase; (5), methylene-THF reductase; (6), Met synthetase; (7), Cysta $\beta$-synthase; (8), $\gamma$-cystathioninase; (9), $\gamma$-glutamyl synthetase; (10), oxidase; (11), reductase; (12), $\gamma$-glutamyl transpeptidase. 
the homozygous C677T state affects from 1 to $15 \%$ of investigated populations (Motulsky, 1996). It seems unlikely that the gene mutation, working alone, contributes to an Hcy-induced increased risk for cardiovascular disease (Brattström, 1997; Reinhardt et al. 1998) but rather potentiates the effects of a pre-existing folate deficiency. A betaine-Hcy methyltransferase $(E C 2.1 .1 .5)$ pathway may serve as a surrogate supplier of Met molecules in mammals (Ericson et al. 1955). The former Met synthase-converting route is cobalamin dependent and widely distributed in animal tissues (Banerjee \& Mathews, 1990). The latter pathway is confined to the liver and kidneys, and utilises betaine as the source of the methyl group (Skiba et al. 1982). Also, Hcy may undergo irreversible degradation along the trans-sulfuration pathway which is initiated by C $\beta S$ activity (Finkelstein, 1990). The enzyme condenses Hcy with serine to form Cysta, which, in turn, is converted to Cys through the activity of $\gamma$-cystathioninase (EC 4.4.1.1; Cooper, 1983). Both of these steps are dependent on pyridoxal 5'-phosphate as a cofactor. Cys is transported to other tissues or it may be oxidised to hypotaurine and taurine (Tau) along the cysteinesulfinate pathway or degraded to $\mathrm{SO}_{4}{ }^{2-}$, its major catabolite (Cooper, 1983; Fig. 1).

Under physiological circumstances, kinetic studies undertaken on healthy adults consuming well-balanced diets with appropriate Met intake levels indicate that both Hcy trans-sulfuration and re-methylation pathways split into nearly equivalent fractions (Storch et al. 1990). These findings are in close concordance with previous clinical investigations (Mudd \& Poole, 1975) and with experiments using perfused rat liver (Finkelstein, 1974) or enzyme preparations (Finkelstein \& Martin, 1984a). In the case of alterations in Met supply, the body exploits its enzymic equipment to modify the respective proportions of Met fluxes driven into re-methylation and trans-sulfuration pathways so as to maintain intra- and extracellular Met homeostasis. The partitioning of Met flow between these two converting routes is reportedly coordinated by the intracellular SAM concentration working as an inhibitor of both methylenetetrahydrofolate (Kutzbach \& Stokstad, 1967) and betaine-Hcy methyltransferase (Finkelstein \& Martin, $1984 b$ ) and as an activator of C $\beta S$ (Finkelstein et al. 1975) enzymes.

Cys undergoes a number of metabolic fates; it may be incorporated into many proteins, keeping its reduced $\mathrm{SH}$ group required to achieve functional properties or reversibly converted to GSH via the $\gamma$-glutamyl cycle (Beutler, 1989). GSH ( $\gamma$-glutamyl-cysteine-glycine) is a tripeptide critically involved in the maintenance of the cellular redox state and the scavenging of free radicals. Its production starts from Cys, and involves glutamic acid and glycine through the activation of two ATP-dependent $\gamma$-glutamyl and glutathione synthetases working in succession (Meister \& Anderson 1983; Beutler, 1989; Fig. 1). In return, GSH may be subsequently cleaved by $\gamma$-glutamyl transpeptidase and dipeptidase enzymes, yielding Cys as the endproduct through cysteinylglycine as an intermediate compound (Cooper, 1983; Beutler, 1989). Cys and GSH may be oxidised to cystine and GSSG, respectively, through the binding of two precursor molecules undergoing oxidation of their $\mathrm{SH}$ groups to form a disulfide $\mathrm{S}-\mathrm{S}$ bridge (Cooper, 1983). GSH is the dominant thiol compound synthesised at millimolar level in all cells, including erythrocytes (Mortensen et al. 1956). GSH is in constant metabolic turnover with a relatively slow biological $T_{\frac{1}{2}}$ of $65 \mathrm{~h}$ in erythrocytes (Mortensen et al. 1956) but forming a very much faster labile pool in hepatocytes (Meister \& Anderson, 1983; Beutler, 1989). The liver GSH reservoir is significantly increased with generous SAA intake (Leaf \& Neuberger, 1947) and depleted in starvation (Tateishi et al. 1977). The data are consistent with the concept that GSH constitutes a hepatic storage and readily available transport form of Cys in animal physiology (Tateishi et al. 1977). Only trace amounts of Cys, cystine and GSSG in the micromolar range are found in animal cells (Cooper, 1983; Meister \& Anderson, 1983).

\section{The essentiality of sulfur in tissue building and metabolic pathways}

$\mathrm{S}$ fulfils essential roles in all living systems, determining the structure and activity of a number of molecules and modulating a myriad of metabolic and catalytic processes. The formation of S-S bonds is grounded on the oxidation of sulfhydryl groups and they form a cornerstone of molecular structures. Intra- or intercatenary $\mathrm{S}-\mathrm{S}$ bridges, occurring during the growth of nascent proteins in the endoplasmic reticulum of eukaryocytic cells, determine their tertiary and quaternary conformations, increasing their thermal stability and resistance to physico-chemical denaturing mechanisms (Betz, 1993). Full protein maturation may require the involvement of sulfonation processes through the activation of a sulfonate group $\left(\mathrm{SO}_{3}{ }^{-}\right)$from the universal donor $3^{\prime}$-phosphoadenosine-5'-phosphosulfate precursor to an appropriate acceptor substrate (Farooqui, 1980). Sulfonation of molecules develops in the cytoplasm of most mammalian cells with the higher activity found in the liver, requiring the activation of two enzyme systems pertaining to a single bifunctional entity ( 3 '-phosphoadenosine-5' -phosphosulfate synthase) and reacting in succession with two ATP molecules (Lyle et al. 1994). The highly charged sulfonate groups remain fully ionised at the $\mathrm{pH}$ encountered in biological systems, favouring electrostatic interactions (Strott, 2002). All types of acceptor molecules may be involved, ranging from less than $10^{3}$ as $\mathrm{MM}$ to greater than $10^{6}$ (Strott, 2002).

Sulfonation is, thus, an important, ubiquitous process taking place along two main pathways in the Golgi network: O-sulfonation mobilises an alcohol group and appears as the dominant reaction in macromolecules such as glycosaminoglycans, proteoglycans and galactoglycerolipids. $\mathrm{N}$-sulfonation necessitates an amide group and plays a crucial role in the alteration of carbohydrate moieties of macromolecules such as heparin and heparan sulfate proteoglycans (Strott, 2002). So far, thirty-two different sulfotransferases located within the Golgi organelles have been recognised and they are capable of causing post-translational changes to the sugar residues of lipid and protein macromolecules (Fukuda et al. 2001). These sulfotransferases are characterised by having high affinity but low capacity. The converting steps are 
reversible as sulfonated products may be subjected to sulfohydrolysis through the activation of specific sulfatases (Parenti et al. 1997). Glucoaminoglycans and proteoglycans fulfil structural or functional roles. They participate in the building of cell membranes, transmembrane signalling and extracellular matrix proteins. They are responsible for the hydration and elasticity of fibrous and cartilaginous joints (Kjéllen \& Lindahl, 1991; Mitchell, 1996). Sphingolipids and galactoglycerolipids are prevalent in myelin, the kidneys and small intestine and are implicated in cell-receptor adhesiveness, blood coagulation and complement activation (Kjéllen \& Lindahl, 1991). Heparin is exclusively produced and stored in mast cells whereas heparan sulfate is more widely distributed (Vos et al. 1994).

Sulfonate esterification of relatively low MM compounds is a widespread biological process. Such reactions take place in the cytosol and are catalysed by a superfamily of soluble sulfotransferases. At least forty-four cytosolic enzymes have been identified and fall into five different families, determined according to their molecular targets and physiological impact (Nagata \& Yamazoe, 2000). Osulfonation processes of tyrosine residues are prevalent post-translational events occurring in all metazoan species (Niehrs et al. 1994) which may lead to either the activation of a biological effect (as reported for thyroid and steroid hormones, and for vitamins) or to its inactivation (as shown for catecholamines and for potentially harmful drugs and xenobiotics) (Huxtable, 1986; Mitchell, 1996). The pituitary-thyroid axis is a major sulfonation target with modulation of the synthesis, metabolism and clearance of the endocrine parameters in several ways. Post-translational sulfonation of thyreostimulin is reportedly capable of enhancing the thyroperoxidase-dependent coupling reaction between iodotyrosine residues (Nlend et al. 1999a) while down-regulating the sulfonation rate of thyroglobulin (Nlend et al. 1999b). Both thyroid hormones thyroxine and triiodothyronine may undergo sulfonation of their phenolhydroxyl group, yielding derivatives characterised by modified biological activity and disposal rates (Visser, 1996). Most hormonal compounds originating from the corticoadrenal glands and sexual organs (cortisol, testosterone, androstenedione, dehydroepiandrosterone, oestradiol, oestrone and pregnenolone) may be subjected to varying degrees of sulfonation regulated by a set of sulfotransferase isoenzymes displaying substrate specificities (Strott, 2002). Sulfonation of steroid molecules could modulate several biological properties, notably brain maturation (Beaulieu, 1998) and the ageing process (Yen, 2001). Catecholamines (adrenaline, noradrenaline, dopamine) are produced by the adrenomedullary cells in free and physiologically active form characterised by a short $\mathrm{T}_{\frac{1}{2}}$ of 1 to $3 \mathrm{~min}$ (Strobel et al. 1994). The bulk (from 73 to $97 \%$ ) of these secretory compounds undergoes sulfoconjugation in phenolsulfotransferase-rich tissues, mainly the gastrointestinal tract (Goldstein et al. 1999). Sulfonated catecholamines thus constitute the preponderant hormonal pool found in human blood, endowed with a considerably longer $\mathrm{T}_{\frac{1}{2}}$ ranging from 3 to $4 \mathrm{~h}$ but devoid of biological potency (Strobel et al. 1994; Onasch et al. 2000). This large reservoir of inactivated molecules represents a circulating pool that is readily available to meet tissue requirements via transformation to bioactive compounds by sulfohydrolysis (Kuchel, 1994). It has been suggested that the sulfonation of bile acids might influence the removal rate of cholesterol (Radominska et al. 1990). Besides the liver, the skin contributes to the bioconversion of steroidogenic molecules. Cholesterol sulfate accumulates in human epidermis and serves as a growth factor, stimulating the differentiation of normal keratinocytes (Jetten et al. 1989). Sulfonation processes also modulate the binding affinities, turnover rates and biological properties of a large number of other endogenous molecules. This is notably illustrated by pituitary glycoprotein hormones such as chorionic gonadotrophin (Bielinska, 1987 ) or luteinising hormone (Parsons \& Pierce, 1980), by gastrointestinal peptides such as cholecystokinin (Williams, 1982) or gastrins (Andersen et al. 1983) and even by vitamins such as ascorbic acid (Tolbert, 1985) and cholecalciferol (Axelson, 1985).

Finally, S may participate in its elemental form to affect the structure and activities of molecules with important roles in normal growth, metabolism, defence, transport and detoxification processes. Sulfhydryl groups are frequently implicated in metal coordination, notably in the conformation of $\mathrm{Zn}$ finger motifs involved in protein-DNA recognition and replication (Pabo et al. 2001). The coupling of GSH to seleno-dependent peroxidase enzyme comprising four identical selenocysteine subunits allows the protection of body tissues from the deleterious effects of organic and inorganic peroxides (Forstrøm et al. 1978; Chance et al. 1979). CoA is a complex molecule condensing adenine, ribose 3 '-phosphate and pantothenic acid with a cysteamine residue bound to the carboxyterminal group of the vitamin. It is a major esterifying thioester serving as an acyl donor for the synthesis of lipids and as a sensor of the metabolic steps converting carbohydrate substrates into energy (Plesofsky-Vig \& Brambi, 1988). The thiamin molecule (vitamin $\mathrm{B}_{1}$ ) possesses a thiazole ring and operates in nonredox enzyme reactions, preventing the occurrence of metabolic abnormalities (Gubler, 1991) associated with the beriberi disease affecting rice-eating populations. Biotin is a bicyclic molecule with an $\mathrm{S}$ moiety within its tetrahydrothiophene ring and works as a cofactor of enzymes involved in the synthesis of fatty acids and in gluconeogenic processes (Zempleni \& Mock, 1999). Metallothioneins are a family of small peptides reaching about $6.5 \mathrm{kDa}$ as $\mathrm{MM}$ whose $\mathrm{AA}$ sequence reveals up to $30 \%$ Cys residues and fulfilling important storage and transport functions, mainly located in the intestinal mucosa, the liver and kidneys (Bremner \& Beattie, 1990). Structural analysis of the six insulin-like growth factor-binding proteins demonstrates the great similarity in their MM ranging from 23 to $31 \mathrm{kDa}$ and in their AA sequence comprising ten to twelve Cys residues (Hwa et al. 1999). Many other Scontaining molecules are recognised of increasing metabolic and nutritional importance.

It is worth noting that the mean Cys content of intracellular proteins in mammalian tissues is about $2 \cdot 5$-fold lower $(1 \cdot 6 v .4 \cdot 1 \%)$ than that of proteins extracellularly exported in biological fluids (Fahey et al. 1977). This is in keeping with distinct biological properties as Cys prevails in the form of sulfhydrated Cys in the former group but is usually oxidised to disulfide proteins in the latter. 


\section{Refractoriness of sulfur-containing molecules to dietary manipulation}

The classical experiments by Finkelstein's group (Finkelstein, 1974; Finkelstein et al. 1975; Finkelstein \& Martin, 1984a,b) and by others (Kutzbach \& Stockstad, 1967) have paved the way for an overall understanding of the enzymic mechanisms regulating Met homeostasis. Dietary Met overload (normally an unlikely condition in human nutrition) occurring under experimental conditions is followed by the intracellular accumulation of SAM which attenuates the activity of re-methylating enzymes and stimulates that of C $\beta S$ (Finkelstein \& Martin, 1986). As a result, the bulk of Met undergoes oxidation along the trans-sulfuration cascade, leading to an increased sulfaturia that is highly correlated with the level of SAA intake (Sabry et al. 1965). The kidney clearance of Met excess allows the maintenance of an unmodified methioninaemia and appears as an important adaptive process especially as Met is considered to be one of the most potentially toxic of the AA (Benevenga, 1974).

Preservation of the endogenous Met pools is also achieved through the coordination of intestinal and renal kinetics. Investigations carried out in normal subjects and using oral perfusion of free AA mixtures have shown that Met displays a rapid and efficient absorption rate (90 to $100 \%$ of intake; Horowitz et al. 1981) compared with most other IAA (Adibi et al. 1967). Moreover, losses of IAA of endogenous origin in the ileostomy fluid of healthy volunteers given a protein-free diet indicate that both Met and Cys together represent $14 \%$ of current daily maintenance requirements, a rate that appears to be below that of all other IAA (Fuller et al. 1994). Furthermore, Met loss compared with Cys represents the smaller fraction among the two SAA compounds (Fuller et al. 1994). Finally, Met reveals very high renal tubular recovery rates (Werder et al. 1966; Stabler et al. 1987) resulting in a barely detectable methioninuria. Even after a significant oral loading test (50 $\mathrm{mg} / \mathrm{kg}$ body weight), Met urinary leakage remains below $1 \%$ of the administered dosage (Horowitz et al. 1981). The high degree of Met retention within endogenous pools thus appears as the net result of salvage mechanisms maximising intestinal absorption rates and minimising faecal and urinary losses. The uniqueness of Met is further documented by animal studies assessing the nutritional consequences of the selective withdrawal of single IAA from balanced AA mixtures. Deleting SAA from an otherwise complete diet causes the greatest rate of body $\mathrm{N}$ loss, nearly equal to that generated by a protein-free diet (Owens \& Bergen, 1983; Fuller et al. 1989). The data are in keeping with rat experiments (Aguilar et al. 1974) and a series of Massachusetts Institute of Technology clinical and metabolic studies (Storch et al. 1990; Hiramatsu et al. 1994; Fukagawa et al. 1996; Raguso et al. 1997) showing that the oxidation rate of Met remains low but constant when its intake level is below requirements (Raguso et al. 1997). This oxidative behaviour is qualitatively very similar to that described for other IAA such as leucine (El-Khoury et al. 1994) or lysine (Meredith et al. 1986) although Met is regarded as the most limiting of the endogenous IAA (Yoshida \& Moritoki, 1974). The maintenance of low but measurable post-absorptive (fasting) rates of Met oxidation unrelated to dietary AA supply supports the view that Met fulfils minimal obligatory activities likely to be of survival importance. Dietary Met manipulation studies performed on healthy adults and using multi-labelled Met as a tracer have shown that the fluxes of both methyl and carboxyl endproducts remain stable (Raguso et al. 1997). This indicates that adaptive changes in the rates of whole-body proteolysis may serve as a mechanism to maintain homeostasis together with the classical re-methylation and trans-sulfuration processes (Kutzbach \& Stokstad, 1967; Finkelstein, 1974; Finkelstein et al. 1975; Finkelstein \& Martin, 1984a,b).

The first investigation correlating $\mathrm{N}$ and $\mathrm{S}$ compounds in healthy human subjects was described by Sherman \& Hawk (1900). The authors investigated the metabolic consequences of a $7 \mathrm{~d}$ period resulting from 'the ingestion of a rather large quantity of protein food when the body is kept in a uniform and perfectly normal condition of nutrition'. In this study, urinary $\mathrm{S}$ catabolites were collected in the form of $\mathrm{SO}_{3}$ compounds and measured by a gravimetric method whereas $\mathrm{N}$ output was determined by Kjeldahl analysis (Fig. 2). It is of interest to note that $\mathrm{SO}_{3}$ values, once converted to elemental $S$, yielded a molar $S: N$ ratio of $1: 13 \cdot 5$, or very close to that characterising the total body chemical composition (Forbes, 1996). More recently, it has been concluded that using sulfate output: (i) depicts a fed-state adaptation to protein restriction in healthy adults (Hamadeh et al. 2001); (ii) can provide an accurate method of estimating SAA catabolism (Hamadeh \& Hoffer, 2001); (iii) may be a useful method to determine the extent of whole-body protein dysregulation in insulin-dependent diabetes mellitus (Hamadeh \& Hoffer, 2003); (iv) allows the N:S balance ratio to serve as a potentially useful indicator of non-protein SAA stores, at least in growing piglets (Hou et al. 2003).

The sparing role played by dietary Cys on Met needs in several animal species (Womack \& Rose, 1941; Baker, 1976; Burns \& Milner, 1981; Finkelstein et al. 1988) has been the topic of a recently revived debate with regard to human nutrition. Earlier investigations undertaken on adult human subjects, taking $\mathrm{N}$ balance as the criterion of intake adequacy, indicated large variability across individuals with a Cys-sparing role ranging from 16 to $90 \%$ of Met requirements (Reynolds et al. 1958; Irwin \& Hegsted, 1971). The estimated mean was about $50 \%$ of the requirement for total SAA (Rose, 1957). However, more recent kinetic studies using stable-isotope techniques in healthy volunteers given tracers either orally (Raguso et al. 1997) or intravenously (Storch et al. 1990) have not confirmed a major capacity of Cys to spare Met unless a very low intake of Met is consumed (Raguso et al. 1997). The bioavailability of Cys is met by the dietary intake, by the conversion of Met through the trans-sulfuration cascade, or by the endogenous breakdown of proteins and of GSH reserves. After oral consumption, Cys is almost entirely removed by intestinal tissues (Rérat et al. 1992), explaining why Met becomes the predominant SAA found in the portal blood flow (Garcia \& Stipanuk, 1992). The large uptake of Cys by the splanchnic (intestine) area thus works as a buffering system so that there is little variation in postprandial Cys values in response to a wide range of Cys 


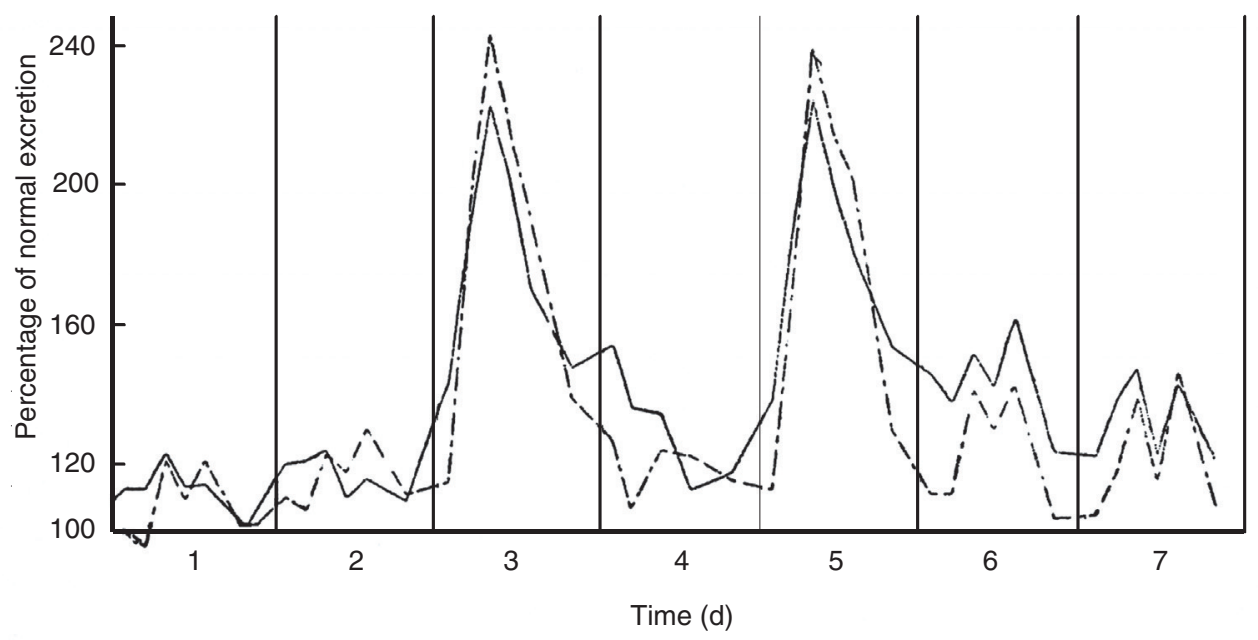

Fig. 2. Evolutionary pattern of a $7 \mathrm{~d} \mathrm{~N}$ and S balance study (Sherman \& Hawk, 1900). Baseline values are normalised to $100 \%$ and result from the daily intake by two healthy subjects (the authors of the publication themselves) of a standard regimen providing $10.9 \mathrm{MJ}(2600 \mathrm{kcal})$ and $15 \mathrm{~g} \mathrm{~N}$. The curves shown here represent the relative fluctuations in the average rates of excretion of $\mathrm{N}(-)$ and of $\mathrm{S}(---)$. An extra supply of $10 \mathrm{~g} \mathrm{~N}$ was ingested in the form of lean beef meat at the start of days 3 and 5 , resulting in the near doubling of $\mathrm{N}$ and $\mathrm{S}$ losses. The study demonstrates that $\mathrm{N}$ and $\mathrm{S}$ excretory rates remain closely correlated under both basal dietary and supplemented conditions.

intake levels (Hiramatsu et al. 1994; Raguso et al. 1997). The liver is the major site of synthesis, sequestration and secretion of GSH, utilising either Cys or Met as precursor substrates (Meister \& Anderson, 1983; Lauterburg \& Smith, 1986; Beutler, 1989). GSH efflux from the liver exceeds $90 \%$ of the total GSH pool found in the bloodstream (Garcia \& Stipanuk, 1992), displaying a $\mathrm{T}_{\frac{1}{2}}$ of $3 \mathrm{~min}$ (Lauterburg et al. 1984). The peripheral breakdown of the S-tripeptide yields its Cys moiety in tissue whose membranes are endowed with $\gamma$-glutamyl-cycle enzymes. In healthy adults, during the post-absorptive (fasting) period, about $55 \%$ of the plasma Cys flux may result from GSH degradation (Fukagawa et al. 1996). An extensive enzymic degradation of GSH occurs in the kidneys which serve as a major supplier of plasma Cys molecules (Abbott et al. 1984; Garcia \& Stipanuk, 1992). It is worth being reminded that mammals are unable to synthesise Met from Cys. The liver is the major organ of Tau synthesis and the kidney is predominantly involved in Tau excretion (Garcia \& Stipanuk, 1992). Part of this last SAA is lost in the biliary flow in the form of taurocholates but may be, to some extent, recovered along the hepatoenteric cycle through the deconjugation of bile salts.

Inorganic $\mathrm{SO}_{4}{ }^{2-}$ is an essential oxyanion required to meet metabolic needs due to its participation in sulfonation processes. The body's requirements are met by $\mathrm{SO}_{4}{ }^{2-}$ via food items, drinking waters and the endogenous breakdown of sulfonated molecules. A minor proportion of dietary $\mathrm{SO}_{4}^{2-}$ may be subjected to bacterial reduction before intestinal uptake (Gibson et al. 1993) but the bulk of $\mathrm{SO}_{4}{ }^{2-}$ undergoes very high absorption rates with negligible faecal loss (Krijgsheld et al. 1979). Several investigations have documented the close relationship linking the amount of $\mathrm{N}$ and/or S intakes and the degree of sulfaturia, confirming the pioneer study performed a century ago (Sherman \& Hawk, 1900). Adult volunteers given three different levels of pro- tein intake excrete in their urinary output $\mathrm{SO}_{4}{ }^{2-}$ values highly correlated $(r 0.88)$ with dietary $\mathrm{N}$ intake (Wright $e t$ al. 1960). Similar high correlations are found in healthy adults submitted, during an $8 \mathrm{~d}$ period, to SAA-deprived regimens and displaying significantly depressed sulfaturia (Lakshmanan et al. 1976). In contrast, stepwise increases in the supply of dietary SAA ranging from normal $(0.8 \mathrm{~g} / \mathrm{d})$ to high $(4 \mathrm{~g} / \mathrm{d})$ levels result in a high correlation $(r 0.98)$ with renal $\mathrm{SO}_{4}{ }^{2-}$ output (Sabry et al. 1965). Under well-balanced dietary conditions, sulfaturia of healthy individuals usually ranges from 20 to $25 \mathrm{mmol} / \mathrm{d}$ (640 to $800 \mathrm{mg} / \mathrm{d}$; Huxtable, 1986), reflecting the amount of ingested S compounds. Taken together, most clinical trials point to complex and narrow interconnections between $\mathrm{N}$ and $\mathrm{S}$ metabolic pathways which are readily up and down regulated so as to maintain steady state plasma concentrations of Met and Cys in a variety of nutritional circumstances. The conclusion also applies to $\mathrm{SO}_{4}{ }^{2-}$ plasma values which are remarkably stable and likewise manifest strong refractoriness to dietary manipulations (Huxtable, 1986).

\section{Regulation of methionine homeostasis in protein- depleted states}

The Massachusetts Institute of Technology clinical and metabolic investigations (Storch et al. 1990; Hiramatsu et al. 1994; Fukagawa et al. 1996; Raguso et al. 1997) mentioned earlier were undertaken in healthy adult volunteers who were given their test diet and meals during a limited number of days. These studies have highlighted that Met homeostasis is achieved via the combined results of small changes in tissue protein breakdown and subtle alterations in the partitioning of Met along re-methylation and transsulfuration pathways. Under longer-lasting or more severe deprivation conditions, Met homeostasis depends upon other and more drastic regulatory mechanisms. Following 
the nature, gravity and duration of dietary deficiencies, several protein-energy malnutrition (PEM) morbidities may develop ranging from overhydrated kwashiorkor cases to emaciated marasmus as extreme clinical forms. Kwashiorkor is a subacute disorder usually taking place during the post-weaning period. It is typically delineated by down-regulated metabolic activities, significant liver steatosis which may serve as an indicator of protein deficiency (Waterlow, 1975), high infectious vulnerability and the depression of protein syntheses, notably those proteins secreted by the liver such as serum albumin and TTR (Ingenbleek et al. 1972; Waterlow, 1992). Marasmus is a chronic disease, causing weight and height retardation, exhaustion of both muscular and lipid compartments but with minimal liver fatty infiltration and relatively well-preserved immune and synthetic capacities. The aminoacidaemia of PEM usually reveals unaltered or elevated dispensable AA concentrations whereas IAA exhibit declining trends, affecting more specifically isoleucine, leucine and valine, the so-called branched-chain AA (Arroyave et al. 1962; Ittyerah et al. 1965). Among the eight IAA, plasma Met concentration remains unmodified in subclinical PEM or marasmus (Polge et al. 1997; Ingenbleek et al. 2002) or falls within a subnormal range in kwashiorkor disorders (Arroyave et al. 1962; Ittyerah et al. 1965). The latter anomaly may be partly explained by the fact that Met is relatively low in vegetable products (Young \& Pellett, 1994) whose nutritive value may be further reduced by food processing (Friedman, 1992). The departure from normal homeostasis also indicates that the usual regulatory mechanisms described by Finkelstein's and Young's groups no longer operate effectively. Distortion from normal is further documented by the very high plasma Met values recorded in PEM children given an exogenous Met supply (Awwaad et al. 1962) or submitted to nutritional rehabilitation (Snyderman et al. 1968). The extraordinarily high Met elevation, ranging from two to thirty-five times normal average levels and persisting during many weeks, has led these last authors to postulate 'some failure in its catabolism' (Snyderman et al. 1968). The data are reminiscent of liver damage similarly characterised by depressed branched-chain AA plasma concentrations and supranormal Met values (Fisher, 1982; Montanari et al. 1988) whose biological $\mathrm{T}_{\frac{1}{2}}$ is significantly increased (Kinsell et al. 1947; Horowitz et al. 1981), again implying an abnormality in the catabolism and removal of Met.

The decline in plasma Met concentration after an oral load follows first-order kinetics and the average clearance rate $(170 \mathrm{ml} / \mathrm{min})$ suggests that Met elimination is not a flow-dependent process (Horowitz et al. 1981). Hypermethioninaemia is reportedly associated with the genetic absence of the higher $\mathrm{K}_{\mathrm{m}} \mathrm{I} / \mathrm{III}$ isoenzyme of Met adenosyltransferase (Gaull \& Tallan, 1974; Finkelstein, 2000). An acquired reduction in Met adenosyltransferase activity to $37.5 \%$ of normal is documented in cirrhotic patients (Cabrero et al. 1988), resulting in a depressed rate of Met to SAM conversion. Histopathological lesions found in liver cirrhosis or steatosis could indeed create a portosystemic vascular shunt, mimicking surgical anastomosis (Baldessarini \& Fisher, 1967) and forcing Met fluxes to bypass the organ. Intrahepatic SAM depression should be proportionate to the extent of liver damage and more affected in kwashiorkor cases than in marasmic forms of malnutrition. As a result, SAM is no longer capable of properly stimulating C $\beta S$ activity, as would be expected from healthy individuals submitted to flooding doses of Met. In cirrhotic patients, the lowering of SAM concentration works as a primary defect causing a uniform reduction in derivatives downstream to Met adenosyltransferases, including that of Hcy, unless there is simultaneously a shrinking of their body $\mathrm{N}$ reserves. In that case, as in PEM patients affected by diminished TBN pools, there is a gradual elevation in the Hcy concentration in extracellular fluids (Ingenbleek et al. 2002). These investigators were the first to postulate the likelihood of an acquired blockade of C $\beta S$ activity as an adaptive response aimed at preserving endangered $\mathrm{N}$ pools. As a general rule in protein metabolism, when the diet is lacking one IAA, the reduced activity of its catabolic enzymes favours a more prolonged conservation of the AA within endogenous pools with increased survival (Carpenter, 1992). Enzymes are protein molecules whose synthesis and/or functional capacities are influenced by changes in $\mathrm{N}$ availability (Stephen, 1968). An enzymeinduced sparing of AA whose intake fails to meet optimal requirements is documented for the other IAA namely lysine (Brookes et al. 1972), tryptophan (Young \& Munro, 1973), threonine (Kang-Lee \& Harper, 1978), phenylalanine (Antener et al. 1981b) and branched-chain AA (Hutson \& Harper, 1981).

The concept that $C \beta S$ activity could remain under the control of $\mathrm{N}$ availability, regardless of SAM status, arose from studies undertaken in 1986 on goitrous patients living in the southern region of Senegal (Ingenbleek et al. 1986). Despite evenly distributed iodine deficiency, goitrous patients revealed significantly different stages I, II and III of thyroid swelling, according to WHO classification (Pérez et al. 1960). Enlargement of the endocrine organ was found to be correlated with declining protein nutritional status as assessed by the measurement of plasma TTR, retinol-binding protein and retinol (Ingenbleek et al. 1980); all three components are closely bound within the trimolecular retinol-circulating complex. The aggravating goitrogenic role played by poor nutritional status was attributed to PEM-induced dysmaturation of thyroglobulin (Ingenbleek \& De Visscher, 1979; Ingenbleek, 1983). In this preliminary survey, TTR values were found to be negatively correlated with Hcy concentrations, and direct C $\beta S$ impairment was the proposed explanation (Ingenbleek et al. 1986). This first investigation was later extended to another iodine-deprived area in the Republic of Chad where goitrous patients were similarly affected by stepwise PEM states of increasing severity (Ingenbleek et al. 2002). Careful attention was given to eliminate from this second study all causal factors which might interfere with the interpretation of TTR and Hcy data. The enlarged battery of biochemical parameters comprised the measurement of the vitamin triad involved in Hcy regulation, that of acute-phase reactants which helped to identify individuals suffering from an underlying inflammatory disorder (Ingenbleek \& Young, 1994), and of thyroid hormonal fractions guiding the removal of cases of hypothyroidism 
as a potential explanation for high Hcy levels (Nedrebø et al. 1998). Values obtained for TTR, for the eight IAA, Hcy and Cysta are summarised in Table 1 showing that all these parameters showed declining trends as protein nutritional status worsened, with the sole exceptions of Met which sustained unmodified levels opposed to the gradual elevation of Hcy values. This latter pattern was unique and the inverse correlation linking TTR and Hcy concentrations is expressed in Fig. 3. The divergent evolution of Hcy and Cysta values point to the progressive inhibition of $C \beta S$ activity under all conditions threatening endogenous $\mathrm{N}$ pools. The data are in agreement with the independent, inverse dose-response relationship existing between the level of protein intake and Hcy values (StolzenbergSolomon et al. 1999). The causality of deficient $\mathrm{N}$ status in the occurrence of acquired hyperhomocysteinaemia must be suspected in all circumstances likely to affect TBN pools such as in weight-reduction programmes (Gallistl et al. 2001), anorexia nervosa (Moyano et al. 1998) or senile dementia (McCaddon et al. 1998) when the vitamin indices remain poorly confirmatory.

Summing up, protein-depleted patients at risk of reduced $\mathrm{N}$ body stores are characterised by a defective conversion of Hcy to Cysta, favouring the upstream accumulation and re-methylation of Hcy to Met owing to the higher $\mathrm{K}_{\mathrm{m}}$ affinity of Met synthase for Hcy compared with C $\beta S$ (Finkelstein, 1974, 2000). The acquired metabolic anomaly is accompanied by increased homocystinuria (Antener et al. 1981a) which contrasts with the fall of most blood and urinary $\mathrm{S}$ catabolites downstream to C $\beta S$, notably that of Cysta (Ingenbleek et al. 2002), Cys (Chawla et al. 1985), GSH (Jackson, 1986; Hum et al. 1992), Tau (Gray et al. 1994) and $\mathrm{SO}_{4}{ }^{2-}$ (Ittyerah, 1969). The exogenous supply of Cys to PEM patients has been shown capable of restoring to some extent the synthesis of GSH in erythrocytes (Baladoo et al. 2002). These abnormalities appear to be more pronounced in kwashiorkor than in marasmic cases and result from the combined effects of both inappropriate dietary intake of

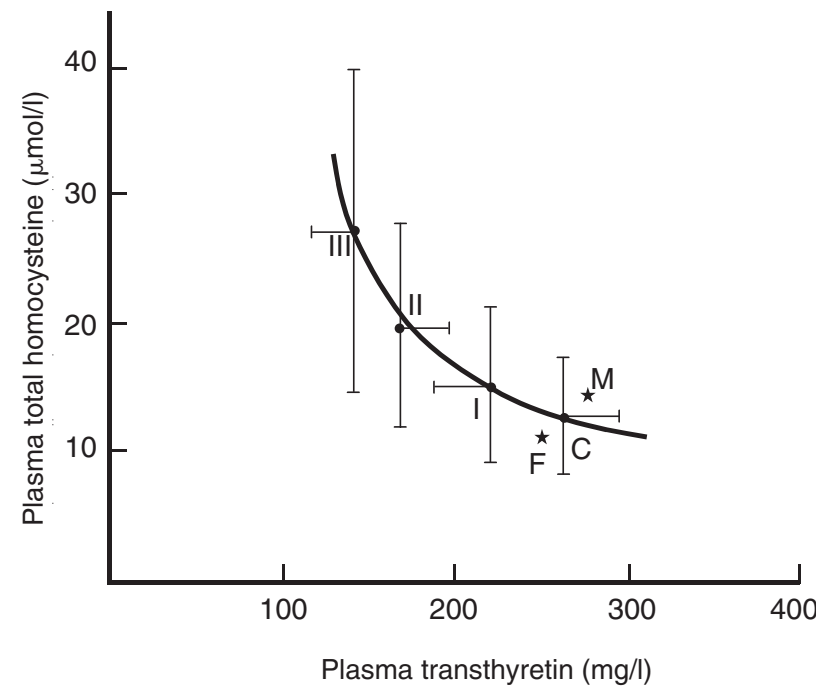

Fig. 3. Measurement of transthyretin (TTR) and homocysteine (Hcy) in control subjects (C) and goitrous patients. WHO recommendations (Pérez et al. 1960) served to classify iodinedeprived individuals into three cohorts representing the stages I, II and III of goitrous swelling. Each of the four groups comprised twenty adult subjects (ten males and ten females). TTR and Hcy values were pooled for interpretation and expressed as means, with standard deviations represented by horizontal and vertical bars. In the $\mathrm{C}$ group, male $(\mathrm{M})$ and female $(\mathrm{F})$ concentrations are shown separately, indicating that both TTR and Hcy manifest sexual difference. The data reveal that declining protein nutritional status, as assessed by the TTR results, is negatively correlated with rising Hcy concentrations.

S-containing molecules and the C $\beta S$ defect. Many investigators have underscored the role played by PEM in the variance of Hcy concentrations probably because they are using serum albumin, transferrin or creatinine which are meagrely sensitive markers of protein status compared with TTR.

Table 1. Plasma concentrations of transthyretin $(\mathrm{mg} / \mathrm{l})$ and of amino acids $(\mu \mathrm{mol} / \mathrm{l})$ in control adults and goitrous patients§ (Mean values and standard deviations)

\begin{tabular}{|c|c|c|c|c|c|c|c|c|c|c|c|}
\hline \multirow{3}{*}{ Variables } & \multirow{2}{*}{\multicolumn{2}{|c|}{ Control group (n 20) }} & \multicolumn{9}{|c|}{ Goitrous patients } \\
\hline & & & \multicolumn{3}{|c|}{ Stage I (n 20) } & \multicolumn{3}{|c|}{ Stage II (n 20) } & \multicolumn{3}{|c|}{ Stage III (n 20) } \\
\hline & Mean & SD & Mean & SD & $\%$ of control & Mean & SD & $\%$ of control & Mean & SD & $\%$ of control \\
\hline Transthyretin & 268 & 31 & $221^{*}$ & 31 & 83 & $171 \dagger$ & 26 & 64 & $146 \ddagger$ & 24 & 55 \\
\hline Lysine & $209 \cdot 3$ & 39 & $173 \cdot 1 \dagger$ & 46 & 82 & $158 \cdot 8 \ddagger$ & 39 & 76 & $131 \cdot 3 \ddagger$ & 23 & 62 \\
\hline Threonine & $199 \cdot 6$ & 51 & $158 \cdot 2^{*}$ & 64 & 79 & $139 \cdot 1 \ddagger$ & 49 & 69 & $125 \cdot 6 \ddagger$ & 29 & 62 \\
\hline Leucine & $179 \cdot 8$ & 37 & 129.6‡ & 41 & 72 & $115 \cdot 1 \ddagger$ & 39 & 64 & $98.3 \ddagger$ & 22 & 54 \\
\hline Isoleucine & $103 \cdot 6$ & 19 & $73 \cdot 7 \dagger$ & 18 & 71 & $59.4 \ddagger$ & 14 & 57 & $50.5 \ddagger$ & 11 & 48 \\
\hline Valine & $258 \cdot 2$ & 47 & $201.0 \dagger$ & 42 & 77 & $170.9 \ddagger$ & 38 & 66 & $139 \cdot 6 \ddagger$ & 21 & 54 \\
\hline Phenylalanine & $98 \cdot 3$ & 14 & $73 \cdot 1^{\star}$ & 21 & 74 & $65.6 \dagger$ & 22 & 66 & $60.3 \ddagger$ & 11 & 61 \\
\hline Tryptophane & 34.5 & $7 \cdot 1$ & $21.8 \dagger$ & $6 \cdot 8$ & 63 & $18 \cdot 6 \ddagger$ & $9 \cdot 1$ & 53 & $16 \cdot 2 \ddagger$ & $5 \cdot 3$ & 46 \\
\hline Methionine & $15 \cdot 2$ & $6 \cdot 1$ & $17 \cdot 2$ & $9 \cdot 4$ & 113 & $14 \cdot 8$ & $6 \cdot 3$ & 97 & $12 \cdot 9$ & $4 \cdot 1$ & 84 \\
\hline Homocysteine & $12 \cdot 7$ & $4 \cdot 7$ & $15 \cdot 2 \dagger$ & $6 \cdot 2$ & 119 & $20 \cdot 1 \neq$ & $8 \cdot 1$ & 158 & $27 \cdot 3 \ddagger$ & $12 \cdot 6$ & 214 \\
\hline Cystathionine & $4 \cdot 08$ & 0.81 & 3.76 & 0.53 & 92 & $3.41 \dagger$ & 0.49 & 84 & $3 \cdot 12 \dagger$ & 0.41 & 76 \\
\hline
\end{tabular}

Mean value was significantly different from that for the control group: ${ }^{*} P<0.05, \dagger P<0.01, \ddagger P<0.001$.

$\S$ Measurements were performed in four cohorts of twenty individuals (ten males and ten females in each cohort). The results for male and female subjects were pooled for interpretation. In the control group, transthyretin and homocysteine were the sole variables exhibiting sexual difference (Ingenbleek et al. 2002). 


\section{Regulation of methionine homeostasis in stressful disorders}

Inflammatory disorders encompass a large cytokineinduced spectrum of metabolic, endocrine and immune alterations developed by the injured body in response to various agents (Wolfe et al. 1989). Rising concentrations of the so-called counter-regulatory hormones (glucocorticoids, insulin, glucagon, somatotrophin) work in concert with cytokines to generate an overall insulin resistance and down-regulation of thyroid function aimed at sparing protein and energy resources in healthy tissues (Ingenbleek \& Bernstein, 1999). In contrast, diseased tissue areas manifest up-regulated events locally promoting defence mechanisms and tissue repair. Taken together, the adaptive changes point to a dichotomous partitioning of the whole body economy (Ingenbleek \& Bernstein, 1999). A salient feature is the strong stimulation of protein turnover as a result of both augmented tissue proteolysis (mainly in the muscle mass) and enhanced specific tissue protein synthesis (mainly in the liver and at the site of injury). The rate of protein degradation generally exceeds the rate at which AA are used for protein syntheses, yielding a net negative $\mathrm{N}$ balance whose magnitude is proportionate to the severity and duration of the stress reaction (Ingenbleek \& Young, 1994; Ingenbleek \& Bernstein, 1999).

Clear evidence that tissue injury of any cause leads to early catabolic losses of both $\mathrm{N}$ and $\mathrm{S}$ substrates came from studies performed by Cuthbertson (1931) in adult individuals with bone fractures. The rise in $\mathrm{N}$ excretion was mainly due to an increased urinary output of urea whereas $\mathrm{S}$ was principally excreted in the form of inorganic $\mathrm{SO}_{4}{ }^{2-}$. The Scottish author stated that the excretory curves of $\mathrm{N}$ and of $\mathrm{S}$ ran closely parallel, reaching a peak within 3 to $6 \mathrm{~d}$ from the initial insult. Moreover, he also predicted, 50 years before the discovery of the roles played by cytokines in stressful disorders, that the increased urinary leakage of urea and $\mathrm{SO}_{4}{ }^{2-}$ as chief products of enhanced muscular catabolism could be due to an 'excessive number of abnormal stimuli (triggering) direct poisoning of the tissue cells such as might be supposed to take place in febrile conditions and in tissue injury'.

The metabolism of Met and S derivatives is complex and not entirely clarified in inflammatory disorders. There is no doubt that GSH is centrally involved in the adaptive responses to stressful stimuli. GSH is indeed implicated in the synthesis of leucotrienes (Anderson et al. 1982), contributes to promote lymphocyte (Dröge et al. 1991) and anti-inflammatory (Bragt \& Bonta, 1980) activities, to neutralise hydrogen organic peroxides (Uhlig \& Wendel, 1992) and to scavenge potentially toxic heterologous products (Meister \& Anderson, 1983; Beutler, 1989). Assuming that an unaltered level of any metabolite results from the balance between synthesis and consumption rates, the increased demand for molecules mediating the adaptive responses to inflammation implies increased rates of production. This is illustrated by the plasma concentrations of Met, Cys and GSH usually found within physiological ranges despite accelerated turnover rates. Met fluxes are significantly enhanced in burned patients and principally directed into SAM transmethylation and Hcy re-methyla- tion pathways whereas the proportion of Met driven into the Hcy trans-sulfuration cascade is relatively diminished (Yu et al. 1993). This suggests that under these conditions of greater turnover rates, Met is oriented towards the feeding of the free AA tissue pools maintaining the $\mathrm{S}$ anabolic drive (Yu et al. 1993). The mechanism underlying this fate of Met appears to be supported by the inhibition of $\gamma$-cystathioninase, an enzyme whose activity seems poorly sensitive to nutritional influences (Viña et al. 1992) but selectively depressed by inflammatory stimuli (Viña et al. 1992; Malmezat et al. 2000a,b). Due to the relative impairment of the trans-sulfuration pathway, the turnover rates of Cys and GSH cannot be fully or directly explained by an increased metabolic conversion of Met but rather depend on the breakdown of endogenous proteins or on the release of tissue reserves. The concept is consistent with studies showing that the production of Cys is not significantly affected when $\gamma$-cystathioninase activity is inhibited (Rao et al. 1990) and that the liver uptake of Cys (presumably of GSH or tissue origin) is paradoxically increased when the enzymic conversion of Met is reduced (Viña et al. 1992). As expected, the inhibition of $\gamma$-cystathioninase activity is accompanied by the upstream accumulation of significant amounts of Cysta in the plasma and the liver of infected rats (Viña et al. 1992; Malmezat et al. 2000b). Well-nourished animals submitted to a sepsis burden manifest increased rates of GSH synthesis seemingly adequate to sustain normal or even high tissue concentrations (Viña et al. 1992; Malmezat et al. 2000b). In contrast, absolute synthesis rate and blood GSH concentrations are found significantly lowered in symptom-free HIV (Buhl et al. 1989; Jahoor et al. 1999) and in burned patients (Mårtensson et al. 1987; Yu et al. 2002), suggesting distinct kinetic regulations between animal models and human subjects. In the case of pre-existing PEM in pigs, GSH status is severely compromised in the intestinal mucosa and in erythrocytes but relatively well preserved in the liver, reflecting a functional priority (Jahoor et al. 1995). In this inflammatory context, the relative independency of Cys from its Met precursor pools as well as its conditionally limited availability for appropriate GSH synthesis confers a relative degree of essentiality to this dispensable AA (Grimble et al. 1992; Viña et al. 1992; Jahoor et al. 1995). It has been shown that an exogenous supply of Cys has beneficial consequences on the response of rats to stress created by TNF $\alpha$ (Grimble et al. 1992). Obviously, the breakdown of endogenous proteins while helping to meet increased tissue Cys requirements simultaneously contributes to a deterioration in $\mathrm{N}$ and $\mathrm{S}$ balances.

The negative $\mathrm{N}$ balance accompanying any hypercatabolic state and typically delineated by $\mathrm{N}$ and $\mathrm{S}$ urinary losses running in parallel (Cuthbertson, 1931) has been subjected to more recent inquiry in burn injury. During the acute stage of injury, the substantial urinary output of urea and of minor $\mathrm{N}$ catabolites, including creatinine and 3methylhistidine (Young \& Munro, 1978), reflects the depletion of both metabolic and structural $\mathrm{N}$ compartments (Ingenbleek \& Young, 2002) whereas the increased cyst(e)inuria, taurinuria and sulfaturia (Larsson et al. 1982) are indicative of the degradation of $\mathrm{S}$ pools. In contrast, the anabolic phase of recovery is characterised by a greatly 
depressed elimination of these $\mathrm{S}$ compounds whose nadir levels coincide with the period of most intense tissue repair (Mårtensson et al. 1987). These urinary patterns are usually associated with an overall shrinking of systemic GSH pools reported in burned patients (Larsson et al. 1982) but also in HIV infection (Buhl et al. 1989) and in many other chronic inflammatory disorders (White et al. 1994). The data are consistent with the greatly reduced bioavailability of these $\mathrm{S}$ compounds measured in the leucocytes of burned patients during the most intense phase of anabolic recovery (Mårtensson et al. 1987). Low GSH concentrations usually persist as long as defence and healing processes are active and maintain a magnified peroxidative burden. The aminoacidaemia found in stressed or septic patients usually displays a reduction by 10 to $30 \%$ of virtually all AA concentrations but with unmodified methioninaemia (Vente et al. 1989), again stressing efficient preservation mechanisms and a relative disconnection of Met from the $\mathrm{S}$ metabolites downstream to $\gamma$-cystathioninase, at least under mild or moderate stressful conditions. The data collected on $\mathrm{N}$ turnover are consistent with the view that both the metabolic pool (comprising organs endowed with rapidly turning over proteins) and the structural pool (mainly made up of muscular and cutaneous proteins with slower turnover rates) participate in the response of the stressed body. However, the balance between these $\mathrm{N}$ compartments is determined by the nature and severity of the injury (Ingenbleek \& Young, 2002). Rat experiments based on long-term tissue labelling with $\left[{ }^{35} \mathrm{~S}\right]$ Met have shown that $\mathrm{S}$ similarly partitions into two distinct compartments characterised by fast and slow turnover rates (Jackson et al. 1968), whose fluctuations seem closely correlated with $\mathrm{N}$ fluxes. Under severe morbid circumstances or in the case of major complications, the regulatory mechanisms governing $\mathrm{N}: \mathrm{S}$ homeostasis may nevertheless be disrupted. A supranormal SAA plasma profile has been described for Cys and Tau as a consequence of renal failure (Vente et al. 1989). The concomitant elevation of Met, Cys and Tau plasma values in septic patients points to severe metabolic disturbances, carrying ominous prognosis significance (Freund $e t$ al. 1979).

\section{Conclusion and recommendations}

$\mathrm{S}$ found in the biosphere is an essential element and cycles in both vegetable and animal kingdoms in close relationship with $\mathrm{N}$. Body composition analysis shows that $\mathrm{S}$ and $\mathrm{N}$ accumulate in mammalian tissues at a molar ratio close to 1:15. Animal requirements for S-containing compounds can be entirely or mainly covered by the dietary intake of Met. The endogenous pools of Met and derivatives, chiefly sequestered within the liver, are very well conserved in part due to the combined effects of minimal gut losses, efficient intestinal uptake and renal recovery rates. In addition, the remarkably constant Met and Hcy plasma concentrations appear to be the net result of subtle competitive mechanisms between re-methylation and trans-sulfuration pathways together with adaptive alterations in the overall homeostasis of Met, depending on its bioavailability. Balance studies performed on healthy adult subjects and using labelled material have shown that the oxidative loss of Met reflects the composition of mixed body proteins and occurs in close relationship with the $\mathrm{N}$ excretion rate (Young et al. 1997; Raguso et al. 1999). Protein malnutrition is characterised by TBN depletion affecting primarily the $\mathrm{N}$ metabolic pool and by urinary excretion of $\mathrm{N}$ and $\mathrm{S}$ catabolites proportionate to the level of tissue breakdown. An enhanced re-methylation rate is favoured by the $\mathrm{N}$ depletion-induced acquired blockade of C $\beta S$ activity, leading to an increased upstream disposal of Hcy. As a consequence, significant homocystinuria may develop, together with decreased urinary losses of S-containing derivatives downstream to $\mathrm{C} \beta \mathrm{S}$. Inflammatory disorders of mild or moderate severity are characterised by the impairment of $\gamma$-cystathioninase activity, an upstream accumulation of Cysta and altered Cys and GSH turnover rates. More aggressive hypercatabolic states usually lead to $\mathrm{N}$ and $\mathrm{S}$ balances becoming even more negative (Cuthbertson, 1931), resulting from the shrinking of both metabolic and structural $\mathrm{N}$ and S compartments (Jackson et al. 1968; Ingenbleek \& Young, 2002).

Although the aetiopathogenic events of stress are basically unrelated to those found in PEM, both conditions may nevertheless similarly endanger $\mathrm{N}$ and $\mathrm{S}$ compartments and threaten life expectancy. The acquired blockade of $\mathrm{C} \beta \mathrm{S}$ activity serves as a salvage mechanism allowing Met to maintain functional properties of survival importance. $\mathrm{N}$ induced hyperhomocysteinaemia thus appears as the dark side of adaptive processes striving to maintain Met homeostasis of the stressed body. The impact of the $\mathrm{N}$ status on the trans-sulfuration pathway is an independent variable unrelated to the effects of the water-soluble vitamin status. In both malnourished and injured patients, Hcy plasma values are negatively correlated with the alterations of body $\mathrm{N}$ compartments. Reduction in the size of TBN, as seen in most debilitating conditions, is faithfully identified by the serial measurement of TTR which also constitutes a valuable tool for monitoring the efficacy of nutritional support and/or antiphlogistic therapy.

Normal TTR concentrations indeed manifest sex- and age-distribution patterns (Ingenbleek \& De Visscher, 1979; Bienvenu et al. 1996) superimposed on those of TBN and mainly explained by a larger proportion of muscle protein in male subjects (Ingenbleek \& Young, 2002). The higher Hcy values found in men (Pancharuniti et al. 1994; LussierCacan et al. 1996) are similarly attributed to the larger fatfree mass characterising healthy male individuals (Dierkes et al. 2001). These sex- and age-related evolutionary patterns point to regulatory mechanisms maintaining from birth to adulthood tight correlations between the size of the TBN compartment and the plasma concentrations of TTR and Hcy. These biological parameters manifest, on the contrary, diverging profiles in healthy elderly individuals likely to result from the genetically programmed shrinking of their structural TBN pools and affecting more markedly elderly males than female counterparts. While TBN and TTR values outline closely correlated declining trends until the end of life (Bienvenu et al. 1996; Ingenbleek \& Young, 2002), Hcy molecules display rising tendencies and accumulate in the body fluids (Rosenberg et al. 1997; Refsum et al. 2004). These data suggest that the regulatory mechanisms set in motion during the pre-senescent period no 
longer operate in the course of ageing. Healthy elderly individuals thus represent a target group incurring an increasing risk for Hcy-related thrombovascular disorders, being even more exposed to any additional factor further depleting their protein status.

Epidemiological studies have clearly established the significance of folate, cobalamin and pyridoxine deficiencies in the causation of augmented Hcy concentrations in several vulnerable population groups. These dietary factors, however, do not sufficiently account for the sizeable proportion of individuals with hyperhomocysteinaemia and who are poorly responsive to vitamin therapy. We are proposing the combined measurement of Hcy and TTR as a means to fill the gap between the recorded public health findings and the vitamin causal factors already recognised to date, allowing the assessment of the additional contribution of subclinical and clinical states of protein malnutrition in the occurrence of the metabolic anomaly.

\section{Acknowledgements}

The authors wish to thank the populations living in the endemic goitrous areas of the Senegalese and Chadian Republics for having agreed to participate in the clinical studies at the origin of a new hyperhomocysteinaemia concept.

\section{References}

Abbott WA, Bridges RJ \& Meister A (1984) Extracellular metabolism of glutathione accounts for its disappearance from the basolateral circulation of the kidney. Journal of Biological Chemistry 259, 15393-15400.

Adibi SA, Gray SJ \& Menden E (1967) The kinetics of amino acid absorption and alteration of plasma composition of free amino acids after intestinal perfusion of amino acid mixtures. American Journal of Clinical Nutrition 20, 24-33.

Aguilar TS, Benevenga NJ \& Harper AE (1974) Effect of dietary methionine level on its metabolism in rats. Journal of Nutrition 104, 761-771.

Andersen BN, Petersen B, Borch K \& Rehfeld JF (1983) Variations in the sulfation of circulating gastrins in gastrointestinal diseases. Scandinavian Journal of Gastroenterology 18, 565-569.

Anderson ME, Allison RD \& Meister A (1982) Interconversion of leukotrienes catalyzed by purified $\gamma$-glutamyltranspeptidase: concomitant formation of leukotriene D4 and $\gamma$-glutamyl amino acids. Proceedings of the National Academy of Sciences USA 79, 1088-1091.

Antener I, Tonney G, Verwilghen AM \& Mauron J (1981a) Biochemical study of malnutrition. IV. Determination of amino acids in the serum, erythrocytes, urine and stool ultrafiltrates. International Journal of Vitamin and Nutrition Research 51, 64-78.

Antener I, Verwilghen AM, van Geert C \& Mauron J (1981b) Biochemical study of malnutrition. V. Metabolism of phenylalanine and tyrosine. International Journal of Vitamin and Nutrition Research 51, 297-306.

Arroyave G, Wilson D, de Funès C \& Béhar M (1962) The free amino acids in blood plasma of children with kwashiorkor and marasmus. American Journal of Clinical Nutrition 11, 517-524.

Awwaad S, Eisa EA \& El-Essawy M (1962) Methionine metabolism in kwashiorkor in Egyptian children. Transactions of the Royal Society of Tropical Medicine and Hygiene 56, 179-181.
Axelson M (1985) 25-Hydroxyvitamin $D_{3} 3$-sulfate is a major circulating form of vitamin D in man. FEBS Letters 191, 171-175.

Baker DH (1976) Nutritional and metabolic interrelationships among sulfur compounds in avian nutrition. Federation Proceedings 35, 1917-1922.

Baladoo A, Reid M, Forrester T, Heird WC \& Jahoor F (2002) Cystein supplementation improves the erythrocyte glutathione synthesis rate in children with severe edematous malnutrition. American Journal of Clinical Nutrition 76, 646-652.

Baldessarini RJ \& Fisher JE (1967) S-adenosylmethionine following portocaval anastomoses. Surgery 62, 311-318.

Banerjee RV \& Mathews RG (1990) Cobalamin-dependent methionine synthase. FASEB Journal 4, 1450-1459.

Beach EF, Teague DM, Hoffman OD, Munks B, Hummel FC, Williams HH \& Macy IG (1942) The sulfur metabolism in children. Journal of Nutrition 24, 257-271.

Beaulieu EE (1998) Neurosteroids: a novel function of the brain. Psychoneuroendocrinology 23, 963-987.

Benevenga NJ (1974) Toxicities of methionine and other amino acids. Journal of Agricultural and Food Chemistry 22, 2-9.

Bergmann L (1981) Aspects of S- and N-metabolism in tissue cultures. In Biology of Inorganic Nitrogen and Sulfur, pp. 341-351 [H Bothe and A Trebst, editors]. Berlin: Springer Verlag.

Betz SF (1993) Disulfide bonds and the stability of globular proteins. Protein Science 2, 1551-1558.

Beutler E (1989) Nutritional and metabolic aspects of glutathione. Annual Review of Nutrition 9, 287-302.

Bielinska M (1987) Sulfation of the choriogonadotrophin $\alpha$-subunit in human placental extracts. Biochemical and Biophysical Research Communications 148, 1446-1452.

Bienvenu J, Jeppson JO \& Ingenbleek Y (1996) Transthyretin (prealbumin) \& retinol-binding protein. In Serum Proteins in Clinical Medicine, pp. 9·011-9·018 [RF Ritchie and O Navolotskaia, editors]. Scarborough: Foundation for Blood Research.

Bragt PC \& Bonta IL (1980) Oxidant stress during inflammation: anti-inflammatory effects of antioxidants. Agents and Actions 10, 536-539.

Brattström L (1997) Common mutation in the methylenetetrahydrofate reductase gene offers no support for mild hyperhomocysteinemia being a causal risk factor for cardiovascular disease. Circulation 96, 3805-3807.

Bremner I \& Beattie JH (1990) Metallothionein and the trace minerals. Annual Review of Nutrition 10, 63-83.

Brookes IM, Owens FN \& Garrigus US (1972) Influence of amino acid level in the diet upon amino acid oxidation by the rat. Journal of Nutrition 102, 27-35.

Buhl R, Holroyd KJ, Mastrangeli A, Cantin AM, Jaffe HA, Wells FB, Saltini C \& Crystal RG (1989) Systemic glutathione deficiency in symptom-free HIV-seropositive individuals. Lancet ii, 1294-1298.

Burns RA \& Milner JA (1981) Sulfur amino acid requirements of immature beagle dogs. Journal of Nutrition 111, 2117-2124.

Cabrero C, Duce AM, Ortiz P, Alemany S \& Mato JM (1988) Specific loss of the high molecular form of S-adenosyl-Lmethionine synthetase in human liver cirrhosis. Hepatology $\mathbf{8}$, 1530-1534.

Cantoni GL (1951) Activation of methionine for transmethylation. Journal of Biological Chemistry 189, 745-754.

Cantoni GL (1985) The role of S-adenosylhomocysteine in the biological utilization of S-adenosylmethionine. Progress in Clinical and Biological Research 198, 47-65.

Carpenter KJ (1992) Protein requirements of adults from an evolutionary perspective. American Journal of Clinical Nutrition 55, 913-917.

Caudill MA, Wang JC, Melnyk S, Pogribny IP, Jernigan S, Collins MD, Santos-Guzman J, Swendseid ME, Cogger EA \& James SJ (2001) Intracellular S-adenosylhomocysteine concentrations predict global DNA hypomethylation in tissues of methyl-defi- 
cient cystathionase- $\beta$-synthase heterozygous mice. Journal of Nutrition 131, 2811-2818.

Chance B, Sies H \& Boveris A (1979) Hydroperoxide metabolism in mammalian organs. Physiological Reviews 59, 527-605.

Chawla RK, Berry CJ, Kutner MH \& Rudman D (1985) Plasma concentrations of transsulfuration pathway products during nasoenteral and intravenous hyperalimentation of malnourished patients. American Journal of Clinical Nutrition 42, 577-584.

Cooper AJL (1983) Biochemistry of sulfur-containing amino acids. Annual Review of Biochemistry 52, 187-222.

Cuthbertson DP (1931) The distribution of nitrogen and sulphur in the urine during conditions of increased catabolism. Biochemical Journal 25, 236-244.

Datko AH, Mudd SH, Giovanelli J \& Macnicol PK (1978) Sulfurcontaining compounds in Lemna perpusilla 6746 grown at a range of sulfate concentrations. Plant Physiology 62, 629-635.

Dierkes J, Jeckel A, Ambrosch A, Westphal S, Luley C \& Boeing $\mathrm{H}$ (2001) Factors explaining the difference of total homocysteine between men and women in the European Investigation into Cancer and Nutrition Potsdam Study. Metabolism 50, 640-645.

Dijkshoorn W \& van Wijk AL (1967) The sulphur requirements of plants as evidenced by the sulphur-nitrogen ratio in the organic matter. A review of published data. Plant and Soil 26, 129-157.

Dröge W, Eck HP, Gmunder H \& Mihm S (1991) Modulation of lymphocyte functions and immune responses by cysteine and cysteine derivatives. American Journal of Medicine 91, Suppl. 3C, 140S-144S.

El-Khoury AE, Fukagawa NK, Sánchez M, Tsay RH, Gleason RE, Chapman TE \& Young VR (1994) The 24-h pattern and rate of leucine oxidation, with particular reference to tracer estimates of leucine requirements in healthy adults. American Journal of Clinical Nutrition 59, 1012-1020.

Ericson LE, Williams JN Jr \& Elvehjem CA (1955) Studies on partially purified betaine-homocysteine transmethylase of liver. Journal of Biological Chemistry 212, 537-544.

Fahey RC, Hunt JS \& Windham GC (1977) On the cysteine and cystine content of proteins. Differences between intracellular and extracellular proteins. Journal of Molecular Evolution 10, 155-160.

Farooqui AA (1980) 3'-Phosphoadenosine 5'-phosphosulfate: metabolism in mammalian tissues. International Journal of Biochemistry 12, 529-535.

Finkelstein JD (1974) Methionine metabolism in mammals: the biochemical basis for homocystinuria. Metabolism 23, 387-398.

Finkelstein JD (1990) Methionine metabolism in mammals. Journal of Nutritional Biochemistry 1, 228-237.

Finkelstein JD (2000) Homocysteine: a history in progress. Nutrition Reviews 58, 193-204.

Finkelstein JD, Kyle WE, Martin JJ \& Pick AM (1975) Activation of cystathionine synthase by adenosylmethionine and adenosylethionine. Biochemical and Biophysical Research Communications 66, 81-87.

Finkelstein JD \& Martin JJ (1984a) Methionine metabolism in mammals. Distribution of homocysteine between competing pathways. Journal of Biological Chemistry 259, 9508-9513.

Finkelstein JD \& Martin JJ (1984b) Inactivation of betaine-homocysteine methyltransferase by adenosylmethionine and adenosylhomocysteine. Biochemical and Biophysical Research Communications 118, 14-19.

Finkelstein JD \& Martin JJ (1986) Methionine metabolism in mammals. Adaptation to methionine excess. Journal of Biological Chemistry 261, 1582-1587.

Finkelstein JD, Martin JJ \& Harris BJ (1988) Methionine metabolism in mammals. The methionine-sparing effect of cystine. Journal of Biological Chemistry 263, 11750-11754.

Fisher JE (1982) Amino acids in hepatic coma. Digestive Diseases Science 2, 97-102.
Flaim KE, Liao WS, Peavy DE, Taylor JM \& Jefferson LS (1982) The role of amino acids in the regulation of protein synthesis in perfused rat liver. Journal of Biological Chemistry 257, 29-46.

Forbes GB (1996) Body composition. In Present Knowledge in Nutrition, 7th ed., pp. 7-12 [EE Ziegler and LJ Filer, editors]. Washington, DC: ILSI Press.

Forstrøm JW, Zakowski JJ \& Tappel AL (1978) Identification of the catalytic site of rat liver glutathione peroxidase as selenocysteine. Biochemistry 17, 2639-2644.

Freund H, Atamian S, Holroyde J \& Fisher JE (1979) Plasma amino acids as predictors of the severity and outcome of sepsis. Annals of Surgery 190, 571-576.

Friedman M (1992) Dietary impact of food processing. Annual Review of Nutrition 12,119-137.

Friedrich JW \& Schrader LE (1978) Sulfur deprivation and nitrogen metabolism in maize seedlings. Plant Physiology 61, 900-903.

Fukagawa NK, Ajami AM \& Young VR (1996) Plasma methionine and cysteine kinetics in response to an intravenous glutathione infusion in adult humans. American Journal of Physiology 270, E209-E214.

Fukuda M, Hiraoka N, Akama TO \& Fukuda MN (2001) Carbohydrate-modifying sulfotransferases: structure, function and pathophysiology. Journal of Biological Chemistry 276, 47747-47750.

Fuller MF, McWilliam R, Wang TC \& Giles LR (1989) The optimum dietary amino acid pattern for growing pigs. 2 Requirements for maintenance and for tissue protein accretion. British Journal of Nutrition 62, 255-267.

Fuller MF, Milne A, Harris CI, Reid TM \& Keenan R (1994) Amino acid losses in ileostomy fluid on a protein-free diet. American Journal of Clinical Nutrition 59, 70-73.

Gallistl S, Sudi KM, Erwa W, Aigner R \& Borkenstein M (2001) Determinants of homocysteine during weight reduction in obese children and adolescents. Metabolism 50, 1220-1223.

Garcia RAG \& Stipanuk MH (1992) The splanchnic organs, liver and kidney have unique roles in the metabolism of sulfur amino acids and their metabolites in rats. Journal of Nutrition 122, 1693-1701.

Gaull GE \& Tallan HH (1974) Methionine adenosyltransferase deficiency: new enzymatic defect associated with hypermethioninemia. Science 186, 49-63.

Gibson GR, Macfarlane GT \& Cummings JH (1993) Sulphate reducing bacteria and hydrogen metabolism in the human large intestine. Gut 34, 437-439.

Giulidori P, Galli-Kienle M, Catto E \& Stramentinoli G (1984) Transmethylation, transsulfuration, and aminopropylation reactions of S-adenosyl-L-methionine in vivo. Journal of Biological Chemistry 259, 4205-4211.

Goldstein DS, Swobda KJ, Miles JM, Coppack SW, Aneman A, Holmes C, Lamensdorf I \& Eisenhofer G (1999) Sources and physiological significance of plasma dopamine sulfate. Journal of Clinical Endocrinology and Metabolism 84, 2523-2531.

Gray GE, Landel AM \& Meguid MM (1994) Taurine-supplemented total parenteral nutrition and taurine status of malnourished cancer patients. Nutrition 10, 11-15.

Grimble RF, Jackson AA, Persaud C, Wride MJ, Delers F \& Engler M (1992) Cysteine and glycine supplementation modulate the metabolic response to tumor necrosis factor $\alpha$ in rats fed a low protein diet. Journal of Nutrition 122, 2066-2073.

Gubler CJ (1991) Thiamin. In Handbook of Vitamins, 2nd ed., pp. 233-281 [LJ Machlin, editor]. New York: Marcel Dekker.

Hamadeh MJ \& Hoffer LJ (2001) Use of sulfate production as a measure of short-term sulfur amino acid catabolism in humans. American Journal of Physiology 280, E857-E866.

Hamadeh MJ \& Hoffer LJ (2003) Effect of protein restriction on sulfur amino acid catabolism in insulin-dependent diabetes mellitus. American Journal of Physiology 284, E382-E389. 
Hamadeh MJ, Schiffrin A \& Hoffer LJ (2001) Sulfate production depicts fed-state adaptation to protein restriction in humans. American Journal of Physiology 281, E341-E348.

Hankey JH \& Eikelboom JM (1999) Homocysteine and vascular disease. Lancet 354, 407-413.

Hart JW \& Filner P (1969) Regulation of sulfate uptake by amino acids in cultured tobacco cells. Plant Physiology 44, $1253-1259$.

Hiramatsu T, Fukagawa NK, Marchini JS, Cortiella J, Yu JM, Chapman TE \& Young VR (1994) Methionine and cysteine kinetics at different intakes of cystine in healthy adult men. American Journal of Clinical Nutrition 60, 525-533.

Holland HD (1974) Aspects of the geologic history of seawater. Origins of Life 5, 87-91.

Horowitz JH, Rypins EB, Henderson JM, Heymsfield SB, Moffitt SD, Bain RP, Chawla RK, Bleier JC \& Rudman D (1981) Evidence for impairment of transsulfuration pathway in cirrhosis. Gastroenterology 81, 668-675.

Hou C, Wykes LJ \& Hoffer LJ (2003) Urinary sulfur excretion and the nitrogen/sulfur balance ratio reveal nonprotein sulfur amino acid retention in piglets. Journal of Nutrition 133, 766-772.

Hum S, Koski KG \& Hoffer LJ (1992) Varied protein intake alters glutathione metabolism in rats. Journal of Nutrition 122, 2010-2018.

Hustad S, Ueland PM, Vollset SE, Zhang Y, Bjørke-Monsen AL \& Schneede J (2000) Riboflavin as a determinant of plasma total homocysteine: effect modification by the methylenetetrahydrofolate reductase C677T polymorphism. Clinical Chemistry 46, 1065-1071.

Hutson SM \& Harper AE (1981) Blood and tissue branched-chain amino and $\alpha$-keto acid concentrations: effect of diet, starvation, and disease. American Journal of Clinical Nutrition 34, 173-183.

Huxtable RJ (1986) Biochemistry of Sulfur. New York: Plenum Publishing Corp.

Hwa V, Oh Y \& Rosenfeld RG (1999) The insulin-like growth factor-binding protein (IGFBP) superfamily. Endocrine Reviews 20, 761-787.

Ingenbleek Y (1983) Vitamin A-deficiency impairs the normal mannosylation, conformation and iodination of thyroglobulin: a new etiological approach to endemic goitre. Experientia 39, Suppl. 44, 264-297.

Ingenbleek Y, Barclay D \& Dirren H (1986) Nutritional significance of alterations in serum amino acid patterns in goitrous patients. American Journal of Clinical Nutrition 43, 310-319.

Ingenbleek Y \& Bernstein L (1999) The stressful condition as a nutritionally dependent adaptive dichotomy. Nutrition 15, 305-320.

Ingenbleek Y \& De Visscher M (1979) Hormonal and nutritional status: critical conditions for endemic goiter epidemiology? Metabolism 28, 9-19.

Ingenbleek Y, De Visscher M \& De Nayer P (1972) Measurement of prealbumin as index of protein-calorie malnutrition. Lancet ii, $106-109$.

Ingenbleek Y, Hardillier E \& Jung L (2002) Subclinical protein malnutrition is a determinant of hyperhomocysteinemia. Nutrition 18, 40-46.

Ingenbleek Y, Luypaert B \& De Nayer P (1980) Nutritional status and endemic goitre. Lancet $\mathbf{i}, 388-392$.

Ingenbleek Y \& Young V (1994) Transthyretin (prealbumin) in health and disease. Annual Review of Nutrition 14, 496-533.

Ingenbleek Y \& Young VR (2002) Significance of transthyretin in protein metabolism. Clinical Chemistry and Laboratory Medicine 40, 1281-1291.

Irwin MI \& Hegsted DM (1971) A conspectus of research in amino acid requirements of man. Journal of Nutrition 101, 539-566.
Ittyerah TR (1969) Urinary excretion of sulfate in kwashiorkor. Clinica Chimica Acta 25, 365-369.

Ittyerah TR, Pereira SM \& Dumm ME (1965) Serum amino acids of children on high and low protein intakes. American Journal of Clinical Nutrition 17, 11-14.

Jackson AA (1986) Blood glutathione in severe malnutrition in childhood. Transactions of the Royal Society of Tropical Medicine and Hygiene 80, 911-913.

Jackson SH, Elliott T, Gero T, Brown F \& Fritz G (1968) Urinary sulfur excretion and whole-body protein catabolism. The effects of burns, age and protein restriction. Clinica Chimica Acta 22, $443-453$

Jahoor F, Jackson A, Gazzard B, Philips G, Sharpstone D, Frazer ME \& Heird W (1999) Erythrocyte glutathione deficiency in symptom-free HIV infection is associated with decreased synthesis rate. American Journal of Physiology 276, E205-E211.

Jahoor F, Wykes LJ, Reeds PJ, Henry JF, del Rosario MP \& Frazer ME (1995) Protein-deficient pigs cannot maintain reduced glutathione homeostasis when subjected to the stress of inflammation. Journal of Nutrition 125, 1462-1472.

Jetten AM, George MA, Nervi C, Boone LR \& Rearick JI (1989) Increased cholesterol sulfate and cholesterol sulfotransferase activity in relation to the multi-step process of differentiation in human epidermal keratinocytes. Journal of Investigative Dermatology 92, 203-209.

Kang SS, Wong PW \& Norusis M (1987) Homocysteinemia due to folate deficiency. Metabolism 36, 458-462.

Kang-Lee TA \& Harper AE (1978) Threonine metabolism in vivo: effect of threonine intake and prior induction of threonine dehydratase in rats. Journal of Nutrition 108, 163-175.

Kelly DP (1980) The sulphur cycle: definition, mechanisms and dynamics. In Sulphur in Biology, CIBA Foundation Symposium no. 72, pp. 3-18 [K Elliot and J Whelan, editors]. Amsterdam: Excerpta Medica.

Kennedy PM (1974) The utilization and excretion of sulphur in cattle fed tropical roughages. Australian Journal of Agricultural Research 25, 1015-1022.

Kinsell LW, Harper HA, Barton HC, Michaels GD \& Weiss HA (1947) Rate of disappearance from plasma of intravenously administered methionine in patients with liver damage. Science 106, 589-590.

Kjéllen L \& Lindahl U (1991) Proteoglycans: structures and interactions. Annual Review of Biochemistry 60, 443-475.

Krijgsheld KR, Frankena H, Scholtens E, Zweens J \& Mulder GJ (1979) Absorption, serum levels and urinary excretion of inorganic sulfate after oral administration of sodium sulfate in the conscious rat. Biochimica et Biophysica Acta 586, 494-500.

Kuchel O (1994) Clinical implications of genetic and acquired defects in catecholamine synthesis and metabolism. Clinical and Investigative Medicine 17, 354-373.

Kutzbach C \& Stokstad ELR (1967) Feedback inhibition of methylene-tetrahydrofolate reductase in rat liver by S-adenosylmethionine. Biochimica et Biophysica Acta 139, 217-220.

Lakshmanan FL, Perera WDA, Scrimshaw NS \& Young VR (1976) Plasma and urinary amino acids and selected sulfur metabolites in young men fed a diet devoid of methionine and cystine. American Journal of Clinical Nutrition 29, 1367-1371.

Larsson J, Liljedahl SO, Mårtensson J, Nordström H, Schildt B \& Sörbo B (1982) Urinary excretion of sulfur amino acids and sulfur metabolites in burned patients receiving parenteral nutrition. Journal of Trauma 22, 656-663.

Lauterburg BH, Adams JD \& Mitchell JR (1984) Hepatic glutathione homeostasis in the rat: efflux accounts for glutathione turnover. Hepatology 4, 586-590.

Lauterburg BH \& Smith CV (1986) Stimulation of hepatic efflux and turnover of glutathione by methionine in the rat. European Journal of Clinical Investigation 16, 494-499. 
Leaf G \& Neuberger A (1947) The effect of diet on the glutathione content of the liver. Biochemical Journal 41, 280-287.

Lussier-Cacan S, Xhignesse M, Piolot A, Selhub J, Davignon J \& Genest J Jr (1996) Plasma total homocysteine in healthy subjects: sex-specific relation with biological traits. American Journal of Clinical Nutrition 64, 587-593.

Lyle S, Stanczak J, Ng K \& Schwartz NB (1994) Rat chondrosarcoma ATP-sulfurylase and adenosine 5'-phosphosulfate kinase reside on a single bifunctional protein. Biochemistry (Mosc) 33, 5920-5925.

McCaddon A, Davies G, Hudson P, Tandy S \& Cattell H (1998) Total serum homocysteine in senile dementia of Alzheimer type. International Journal of Geriatric Psychiatry 13, 235-239.

McCully KS (1996) Homocysteine and vascular disease. Nature Medicine 2, 386-389.

Malmezat T, Breuillé D, Capitan P, Mirand PP \& Obled C (2000a) Glutathione turnover is increased during the acute phase of sepsis in rats. Journal of Nutrition 130, 1239-1246.

Malmezat T, Breuillé D, Pouyet C, Buffière C, Denis P, Patureau Mirand P \& Obled C (2000b) Methionine transsulfuration is increased during sepsis in rats. American Journal of Physiology 279, E1391-E1397.

Mårtensson J, Larsson J \& Nordström H (1987) Amino acid metabolism during the anabolic phase of severely burned patients: with special reference to sulphur amino acids. European Journal of Clinical Investigation 17, 130-135.

Meister A \& Anderson ME (1983) Glutathione. Annual Review of Biochemistry 52, 711-760.

Meredith CN, Wen ZM, Bier DM, Matthews DE \& Young VR (1986) Lysine kinetics at graded lysine intakes in young men. American Journal of Clinical Nutrition 43, 787-794.

Mitchell SC (1996) Biological Interactions of Sulfur Compounds. London: Taylor \& Francis.

Mohr H \& Schopfer P (1994) Plant Physiology. Berlin: Springer Verlag.

Montanari A, Simoni I, Vallisa D, Trifiro A, Colla R, Abbiati R, Borghi L \& Novarini A (1988) Free amino acids in plasma and skeletal muscle of patients with liver cirrhosis. Hepatology $\mathbf{8}$, 1034-1039.

Mortensen RA, Haley MI \& Elder HA (1956) The turnover of erythrocyte glutathione in the rat liver. Journal of Biological Chemistry 218, 268-273.

Motulsky AG (1996) Nutritional ecogenetics: homocysteinerelated arteriosclerotic vascular disease, neural tube defects, and folic acid. American Journal of Human Genetics 58, 17-20.

Moyano D, Vilaseca MA, Artuch R, Valls C \& Lambruschini N (1998) Plasma total-homocysteine in anorexia nervosa. European Journal of Clinical Nutrition 52, 172-175.

Mudd SH \& Poole JR (1975) Labile methyl balances for normal humans on various dietary regimens. Metabolism 24, 721-735.

Mueller JH (1923) A new sulphur-containing amino acid isolated from hydrolytic products of protein. Journal of Biological Chemistry 56, 157-169.

Nagata K \& Yamazoe Y (2000) Pharmacogenetics of sulfotransferase. Annual Review of Pharmacology and Toxicology 40, $159-176$

Nedreb $\varnothing$ BG, Ericsson UB, Nygård O, Refsum H, Ueland PM, Aakvaag A, Aanderud S \& Lien EA (1998) Plasma total homocysteine levels in hyperthyroid and hypothyroid patients. Metabolism 47, 89-93.

Niehrs C, Beisswanger R \& Huttner WB (1994) Protein tyrosine sulfation, 1993 - an update. Chemico-Biological Interactions 92, 257-271.

Nlend MC, Cauvi D, Venot N \& Chabaud O (1999a) Sulfated tyrosines of thyroglobulin are involved in thyroid hormone synthesis. Biochemical and Biophysical Research Communications 262, 193-197.
Nlend MC, Cauvi D, Venot N, Desruisseau S \& Chabaud O (1999b) Thyrotropin regulates tyrosine sulfation of thyroglobulin. European Journal of Endocrinology 141, 61-69.

Onasch A, Tanzeem A, Isgro F, Boning D \& Strobel G (2000) Effect of intravenous dopamine infusion on plasma concentrations of dopamine and dopamine sulfate in men, during and up to $18 \mathrm{~h}$ after infusion. European Journal of Pharmacology 55, $755-759$.

Owens FN \& Bergen WG (1983) Nitrogen metabolism in ruminant animals: historical perspective, current understanding and future implications. Journal of Animal Sciences 57, Suppl. 2, 498-518.

Pabo CO, Peisach E \& Grant RA (2001) Design and selection of novel $\mathrm{Cys}_{2} \mathrm{His}_{2}$ zinc finger proteins. Annual Review of Biochemistry 70, 313-340.

Pancharuniti N, Lewis CA, Sauberlich HE, Perkins LL, Go RCP, Alvarez JO, Macaluso A, Acton RT, Copeland RB, Cousins AL, Gore TB, Cornwell PE \& Roseman JM (1994) Plasma homocyst(e)ine, folate, and vitamin B-12 concentrations and risk for early-onset coronary artery disease. American Journal of Clinical Nutrition 59, 940-948.

Parenti G, Meroni G \& Ballabio A (1997) The sulfatase gene family. Current Opinion in Genetics and Development 7, 386-391.

Parsons TF \& Pierce JG (1980) Oligosaccharide moieties of glycoprotein hormones: bovine lutropin resists enzymatic deglycosylation because of terminal O-sulfated $\mathrm{N}$-acetylhexosamines. Proceedings of the National Academy of Sciences USA 77, 7089-7093.

Pérez C, Scrimshaw NS \& Muñoz JA (1960) Endemic Goitre, WHO Monograph Series no. 44. Geneva: WHO.

Peters JP \& Van Slijke DD (1931) Quantitative Clinical Chemistry, vol. I, Interpretations. Baltimore: The Williams \& Wilkins Co.

Plesofsky-Vig N \& Brambi R (1988) Pantothenic acid and coenzyme A in cellular modification of proteins. Annual Review of Nutrition 8, 461-482.

Polge A, Bancel E, Bellet H, Strubel D, Poirey S, Peray P, Carlet C \& Magnan de Bornier B (1997) Plasma amino acid concentrations in elderly patients with protein energy malnutrition. Age and Ageing 26, 457-462.

Radominska A, Comer KA, Zimniak P, Falany J, Iscan M \& Falany CN (1990) Human liver steroid sulphotransferase sulphates bile acids. Biochemical Journal 272, 597-604.

Raguso CA, Ajami AM, Gleason R, Young VR (1997) Effect of cystine intake on methionine kinetics and oxidation determined with oral tracers of methionine and cysteine in healthy adults. American Journal of Clinical Nutrition 66, 283-292.

Raguso CA, Pereira P \& Young VR (1999) A tracer investigation of obligatory oxidative amino acid losses in healthy, young adults. American Journal of Clinical Nutrition 70, 474-483.

Rao AM, Drake MR \& Stipanuk MH (1990) Role of the transsulfuration pathway and of $\gamma$-cystathioninase activity in the formation of cysteine and sulfate from methionine in rat hepatocytes. Journal of Nutrition 120, 837-845.

Refsum H, Smith AD, Ueland PM, Nexo E, Clarke R, McPartlin J, Johnston C, Engbaek F, Schneede J, McPartlin C \& Scott JM (2004) Facts and recommendations about total homocysteine determinations: an expert opinion. Clinical Chemistry 50,3-32.

Reinhardt D, Sigusch HH \& Vogt SF (1998) Absence of association between a common mutation in the methylenetetrahydrofolate reductase gene and the risk of coronary artery disease. European Journal of Clinical Investigation 28, 20-23.

Rérat A, Simoes-Nuñez C, Mendy T, Vaissade P \& Vaugelade P (1992) Splanchnic fluxes of amino acids after duodenal infusion of carbohydrate solutions containing free amino acids or oligopeptides in the non-anaesthesized pig. British Journal of Nutrition 68, 111-138. 
Reuveny Z \& Filner P (1977) Regulation of adenosine triphosphate sulfurylase in cultured tobacco cells. Effects of sulfur and nitrogen sources on the formation and decay of the enzyme. Journal of Biological Chemistry 252, 1858-1864.

Reynolds MS, Steel DL, Jones EM \& Baumann CA (1958) Nitrogen balances of women maintained on various levels of methionine and cystine. Journal of Nutrition 64, 99-111.

Rose WC (1957) The amino acid requirements of adult man. Nutrition Abstracts and Reviews 27, 631-647.

Rosenberg IH, Selhub J, Jacques PF, Bowman BA, Gunter EW, Johnson CL \& Murphy RS (1997) Blood homocysteine levels in the national health and nutrition examination survey (NHANES III) in the United States: preliminary findings by age and sex. In International Conference on Homocysteine Metabolism: from Basic Science to Clinical Medicine, pp. 183-187 [I Graham, H Refsum, IH Rosenberg and PM Ueland, editors]. Norwell, MA: Kluwer Academic.

Rudland PS \& Clark BFC (1972) Polypeptide chain initiation and the role of a methionine tRNA. In The Mechanism of Protein Synthesis and its Regulation, pp. 55-131 [L Bosch, editor]. Amsterdam: North-Holland Publishing Co.

Sabry ZI, Shadarevian SB, Cowan JW \& Campbell JA (1965) Relationship of dietary intake of sulphur amino-acids to urinary excretion of inorganic sulphate in man. Nature 206, 931-933.

Sherman HC \& Hawk PB (1900) On the elimination of nitrogen, sulphates, and phosphates after the ingestion of proteid food. American Journal of Physiology 4, 25-49.

Skiba WE, Taylor MP, Wells MS, Mangum JH \& Awad WM Jr (1982) Human hepatic methionine biosynthesis. Purification and characterization of betaine:homocysteine S-methyltransferase. Journal of Biological Chemistry 257, 14944-14948.

Smith IK (1975) Sulfate transport in cultured tobacco cells. Plant Physiology 55, 303-307.

Snydermann SE, Holt LE Jr, Norton PM, Roitman E \& Phansalkar SV (1968) The plasma aminogram. I. Influence of the level of protein intake and a comparison of whole protein and amino acid diets. Pediatric Research 2, 131-144.

Stabler SP, Allen RH, Savage DG \& Lindenbaum K (1990) Clinical spectrum and diagnosis of cobalamin deficiency. Blood 76, 871-881.

Stabler SP, Marcell PD, Podell ER \& Allen RH (1987) Quantitation of total homocysteine, total cysteine and methionine in normal serum and urine using capillary gas chromatography-mass spectrometry. Analytical Biochemistry 162, 185-196.

Stephen JML (1968) Adaptive enzyme changes in liver and muscle of rats during protein depletion and refeeding. British Journal of Nutrition 22, 153-163.

Stolzenberg-Solomon NZ, Miller ER, Maguire MG, Selhub J \& Appel LJ (1999) Association of dietary protein intake and coffee consumption with serum homocysteine concentrations in an older population. American Journal of Clinical Nutrition 69, 467-475.

Storch KJ, Wagner DA, Burke JF \& Young VR (1990) $\left[1-{ }^{13} \mathrm{C}\right.$; methyl- ${ }^{2} \mathrm{H}_{3}$ ]methionine kinetics in humans: methionine conservation and cystine sparing. American Journal of Physiology 258, E790-E798.

Strobel G, Friedmann B, Jost J \& Bärtsch P (1994) Plasma and platelet catecholamine and catecholamine sulfate response to various exercise tests. American Journal of Physiology 267, E537-E543.

Strott CA (2002) Sulfonation and molecular action. Endocrine Reviews 23, 703-732.

Sult WV \& Kulp JL (1959) Isotopic geochemistry of sulphur. Geochimica et Cosmochimica Acta 16, 201-235.

Tateishi N, Higashi T, Naruse A, Nakashima K, Shiozaki H \& Sakamoto Y (1977) Rat liver glutathione: possible role as a reservoir of cysteine. Journal of Nutrition 107, 51-60.
Tolbert BM (1985) Metabolism and function of ascorbic acid and its metabolites. International Journal of Vitamin and Nutrition Research 27, Suppl., 121-138.

Ubbink JB (1997) Vitamin status and hyperhomocysteinemia in a healthy population. In International Conference on Homocysteine Metabolism: from Basic Science to Clinical Medicine, pp. 93-98 [I Graham, H Refsum, IH Rosenberg and PM Ueland, editors]. Norwell, MA: Kluwer Academic.

Ubbink JB, van der Merwe A, Delport R, Allen RH, Stabler SP, Riezler R \& Vermaak WJH (1996) The effect of a subnormal vitamin B-6 status on homocysteine metabolism. Journal of Clinical Investigation 98, 177-184.

Uhlig S \& Wendel A (1992) The physiological consequences of glutathione variations. Life Sciences 51, 1083-1094.

Vente JP, von Meyenfeldt MF, van Eijk HMH, van Berlo CLH, Gouma DJ, Van der Linden CJ \& Soeters PB (1989) Plasmaamino acid profiles in sepsis and stress. Annals of Surgery 209, $57-62$

Viña J, Gimenez A, Puertes IR, Gasco E \& Viña JR (1992) Impairment of cysteine synthesis from methionine in rats exposed to surgical stress. British Journal of Nutrition 68, 421-429.

Visser TJ (1996) Role of sulfate in thyroid hormone sulfation. European Journal of Endocrinology 134, 12-14.

Vos JP, Lopes-Cardozo M \& Gadella BM (1994) Metabolic and functional aspects of sulfogalactolipids. Biochimica et Biophysica Acta 1211, 125-149.

Wächtershäuser G (2000) Life as we don’t know it. Science 289, 1307-1308.

Waterlow JC (1975) Amount and rate of disappearance of liver fat in malnourished infants in Jamaica. American Journal of Clinical Nutrition 28, 1330-1336.

Waterlow JC (1992) Protein-Energy Malnutrition. London: Edwards Arnold.

Weir DG \& Scott JM (1998) Homocysteine as a risk factor for cardiovascular and related disease: nutritional implications. Nutrition Research Reviews 11, 311-338.

Werder EA, Curtius HC, Tancredi F, Anders PW \& Prader A (1966) Homocystinurie. Helvetica Paediatrica Acta 21, 1-18.

White AC, Thannickal VJ \& Fanburg BL (1994) Glutathione deficiency in human disease. Journal of Nutritional Biochemistry $\mathbf{5}$, 218-226.

Williams JA (1982) Cholecystokinin: a hormone and neurotransmitter. Biomedical Research 3, 107-121.

Winnewisser G \& Herbst E (1987) Organic molecules in space. Topics in Current Chemistry 139, 119-172.

Wolfe RR, Jahoor F \& Hartl WH (1989) Protein and amino acid metabolism after injury. Diabetes and Metabolism Reviews 5, 149-164.

Womack M, Kemmerer KS \& Rose WC (1937) The relation of cysteine and methionine to growth. Journal of Biological Chemistry 121, 403-410.

Womack M \& Rose WC (1941) Partial replacement of dietary methionine by cystine for purposes of growth. Journal of Biological Chemistry 141, 375-379.

Wright JB, Martin PG, Skellenger ML \& Moschette DS (1960) Metabolic patterns in preadolescent children. III. Sulfur balance on three levels of nitrogen intake. Journal of Nutrition $\mathbf{7 2}$, 314-316.

Yen SSC (2001) Dehydroepiandrosterone sulfate and longevity: new clues for an old friend. Proceedings of the National Academy of Sciences USA 98, 8167-8169.

Yoshida A \& Moritoki K (1974) Nitrogen sparing action of methionine and threonine in rats receiving a protein free diet. Nutrition Reports International 9, 159-168.

Young VR \& Munro HN (1973) Plasma and tissue tryptophan levels in relation to tryptophan requirements of weanling and adult rats. Journal of Nutrition 103, 1759-1763. 
Young VR \& Munro HN (1978) N $\tau$-methylhistidine (3-methylhistidine) and muscle protein turnover: an overview. Federation Proceedings 37, 2291-2300.

Young VR \& Pellett PL (1994) Plant proteins in relation to human protein and amino acid nutrition. American Journal of Clinical Nutrition 59, 1203S-1212S.

Young VR, Yu YM, Fukagawa NK \& Raguso CA (1997) Methionine kinetics and balance. In International Conference on Homocysteine Metabolism: from Basic Science to Clinical Medicine, pp. 11-22 [I Graham, H Refsum, IH Rosenberg and PM Ueland, editors]. Norwell, MA: Kluwer Academic.
Yu Y, Burke JF \& Young VR (1993) A kinetic study of $\mathrm{L}^{-2} \mathrm{H}_{3}$ methyl-1-13 $\mathrm{C}$-methionine in patients with severe burn injury. Journal of Trauma 35, 1-7.

Yu YM, Ryan CM, Fei ZW, Lu XM, Castillo L, Schultz JT, Tompkins RG \& Young VR (2002) Plasma L-5-oxoproline kinetics and whole body glutathione synthesis rates in severely burned adult patients. American Journal of Physiology 282, E247-E258.

Zempleni J \& Mock DM (1999) Biotin biochemistry and human requirements. Journal of Nutritional Biochemistry 10, $128-138$ 
https://doi.org/10.1079/NRR200489 Published online by Cambridge University Press 